Article

\title{
Chemical Weathering and Riverine Carbonate System Driven by Human Activities in a Subtropical Karst Basin, South China
}

\author{
Xiaoxi Lyu ${ }^{1} ®$, Zhen Tao ${ }^{1,2}$, Quanzhou Gao ${ }^{1,2, *}$, Haixia Peng ${ }^{1}$ and Mei Zhou ${ }^{1}$ \\ 1 School of Geography and Planning, and Guangdong Provincial Key Laboratory for Urbanization and \\ Geo-simulation, Sun Yat-sen University, Guangzhou 510275, China; 1xxcas@163.com (X.L.); \\ taozhen@mail.sysu.edu.cn (Z.T.); phaixia369@163.com (H.P.); meidaidai@126.com (M.Z.) \\ 2 Guangdong Provincial Key Laboratory of Mineral Resource \& Geological Processes, Sun Yat-sen University, \\ Guangzhou 510275, China \\ * Correspondence: eesgqz@mail.sysu.edu.cn; Tel: +86-20-84115579
}

Received: 19 September 2018; Accepted: 23 October 2018; Published: 26 October 2018

check for updates

\begin{abstract}
In the context of climate change, the input of acid substances into rivers, caused by human activities in the process of industrial and agricultural development, has significantly disrupted river systems and has had a profound impact on the carbon cycle. The hydrochemical composition and which main sources of the Lianjiang River (LR), a subtropical karst river in northern Guangdong Province, South China, were analyzed in January 2018. The objective was to explicate the influence on the deficit proportion of $\mathrm{CO}_{2}$ consumption, resulting from carbonate chemical weathering (CCW), driven by nitric acid $\left(\mathrm{HNO}_{3}\right)$ and sulfuric acid $\left(\mathrm{H}_{2} \mathrm{SO}_{4}\right)$, which is affected by exogenous acids from the industrial regions in north of the Nanling Mountains and the Pearl River Delta. The response of the riverine carbonate system to exogenous acid-related weathering was also discussed. $\mathrm{HCO}_{3}{ }^{-}$ and $\mathrm{Ca}^{2+}$, respectively, accounted for $84.97 \%$ of the total anions and $78.71 \%$ of the total cations in the surface runoff of the LR, which was characterized as typical karst water. CCW was the most important material source of river dissolved loads in the LR, followed by human activities and silicate chemical weathering (SCW). Dissolved inorganic carbon (DIC), derived from CCW induced by carbonic acid $\left(\mathrm{H}_{2} \mathrm{CO}_{3}\right)$, had the largest contribution to the total amount of DIC in the LR $(76.79 \%)$, and those from $\mathrm{CCW}$ induced by anthropogenic acids $\left(\mathrm{HNO}_{3}\right.$ and $\left.\mathrm{H}_{2} \mathrm{SO}_{4}\right)$ and $\mathrm{SCW}$ contributed $13.56 \%$ and $9.64 \%$ to the total DIC, respectively. The deficit proportion of $\mathrm{CO}_{2}$ consumption associated with $\mathrm{CCW}$ resulting from sulfuric acid and nitric acid (13.56\%), was slightly lower than that of the Guizhou Plateau in rainy and pre-rainy seasons ( $15.67 \%$ and $14.17 \%$, respectively). The deficit percentage of $\mathrm{CO}_{2}$ uptake associated with CCW induced by sulfuric acid and nitric acid, accounted for $38.44 \%$ of the total $\mathrm{CO}_{2}$ consumption related to natural CCW and $18.84 \%$ of the anthropogenic acids from external areas. DIC derived from CCW induced by human activities, had a significant positive correlation with the total alkalinity, SIc and $p \mathrm{CO}_{2}$ in river water, indicating that the carbonate system of the LR was also driven by exogenous acids, with the exception of carbonic acid. More attention should be paid to the effects of human activities on the chemical weathering and riverine carbonate system in the karst drainage basin.
\end{abstract}

Keywords: karst basin; carbonate weathering; carbonate system; dissolved inorganic carbon; anthropogenic acids; the Lianjiang River 


\section{Introduction}

A river system is one of the most important transport channels of material and energy to the ocean in a drainage basin, which records the environment evolution processes of the river basin. Chemical weathering processes in a drainage basin can be reflected by the river hydrochemical characteristics [1,2], which is the main part of the mass exchange between the ocean and the continent. It is generally recognized that silicate chemical weathering (SCW) induced by carbonic acid is a net depletion process of the atmospheric/soil $\mathrm{CO}_{2}$. However, the $\mathrm{CO}_{2}$ consumed by carbonate chemical weathering $(\mathrm{CCW})$ associated with carbonic acid will return to the atmosphere with the precipitation of carbonate minerals on a geological time scale ( $>1 \mathrm{Ma}$ ). Thus, CCW only affects global climate change on a short time scale [3]. Recently, some scholars have discovered that organic carbon can be produced by natural aquatic ecosystems through photosynthesis or directly by using dissolved inorganic carbon (DIC), which is derived from CCW and is rich in karst river (the fertilizing effect of DIC), that enters the lithosphere through sedimentation and burial [4-6]. The $\mathrm{CO}_{2}$ consumption associated with CCW have not only controlled climate change over a short time scale, but also dominated long-term climate change, since the emergence of aquatic photosynthetic organisms [7-9].

The karst basin ecosystem is subject to greater climate stress and intensifying human activities, which profoundly affect the river carbon cycle, and exhibits a higher sensitivity [10]. With the development of urbanization, human activities (e.g., acid deposition, industrial and domestic sewage discharge, nitrogen fertilizer application, etc.) have gradually become an important factor influencing the chemical composition of river water. More and more studies have paid attention to the CCW influenced by nitric acid or sulfuric acid, which is derived from industrial and agricultural activities [11-18]. Strong acid, such as sulfuric acid or nitric acid derived from anthropogenic sources, replaces carbonic acid agent and dissolves rocks in the process of rock chemical weathering. It also disturbs the rock weathering and the associated $\mathrm{CO}_{2}$ consumption in natural conditions. Li et al. [19] analyzed the source of sulfate in the Jialingjiang River using stable isotopes $\left(\delta^{34} \mathrm{~S}\right.$ and $\left.\delta^{18} \mathrm{O}\right)$ and found that domestic and industrial wastewater was an important source of sulfate. They also confirmed that sulfuric acid derived from the atmospheric input of high sulfur coal combustion was a weathering agent involved in rock weathering.

Chemical weathering in the drainage basin and fluvial chemical composition are more susceptible to human activities owing to the rapid dissolution kinetics of carbonate rocks and the special binary and three-dimensional geological structure in the karst area. A case study of two karst basins in Southern France showed that CCW induced by nitric acid, which was derived from nitrogen fertilizer, accounted for 30\% [20] and 12-26\% [21]. The study on the glacial runoff by Anderson et al. [22] showed that the amount of carbonate rocks dissolved by sulfuric acid constituted $22 \%$ of the total dissolved carbonates. Chemical weathering of surface rocks is a basic geological process, which converts atmospheric/soil $\mathrm{CO}_{2}$ to DIC [23]. Generally, the DIC in the karst surface waters is mainly derived from carbonate rocks dissolved by carbonic acid. With the interference of human activities, the DIC produced by CCW induced by sulfuric acid and nitric acid may be an important part of the DIC flux in the karst surface water. Li et al. [24] reported that about 13\% of DIC in the Yalongjiang River Basin in Southwest China was due to the involvement of sulfuric acid in CCW.

However, no atmospheric/soil $\mathrm{CO}_{2}$ was consumed by $\mathrm{CCW}$ associated with strong acids. On the contrary, $\mathrm{CCW}$ with strong acids (especially sulfuric acid) has a net $\mathrm{CO}_{2}$ release process on geological time scales [25], and Jiang [16] concluded that the atmospheric/soil $\mathrm{CO}_{2}$ consumption of CCW should be strictly evaluated if sulfuric acid or nitric acid was involved by analyzing the main ions and $\delta^{13} C_{\text {DIC }}$ in the Nandong subterranean stream. Therefore, the carbon sink effect related to CCW needs to be reevaluated if sulfuric acid or nitric acid exists in a carbonate catchment. Perrin et al. [13] estimated that the $\mathrm{CO}_{2}$ produced during $\mathrm{CCW}$ by nitric acid, which was derived from the nitrification of nitrogen fertilizers in the agricultural region of Southeastern France and around the world, were 2.2-5.3 $\times 10^{5} \mathrm{t} \cdot \mathrm{a}^{-1}$ and $1.2-2.9 \times 10^{7} \mathrm{t} \cdot \mathrm{a}^{-1}$, respectively. Liu et al. [26] calculated the contribution of acid precipitation to the chemical composition of the Qiantangjiang River by the Galy Model and 
concluded that the estimated $\mathrm{CO}_{2}$ consumption rate was $23 \%$ lower than that before deducting sulfuric acid weathering, if sulfuric acid involvement was considered. As a result, CCW is disturbed to varying degrees under the influence of human activities. This is of great significance for the accurate identification of the role of exogenous acids during the chemical weathering process in drainage basins in evaluating the interference of human activities with CCW and gaining an insight into the current global climate change and carbon cycle. However, the CCW processes involving strong anthropogenic acids have not yet received sufficient attention in the current global carbon cycle model [15].

Due to the slower dissolution kinetics and lower solubility of silicate than those of carbonate, the $\mathrm{CO}_{2}$ consumption related to SCW in the karst watershed and clastic interlayers of carbonate rocks has been ignored, and all of the $\mathrm{HCO}_{3}{ }^{-}$was attributed to the contribution of CCW in previous studies $[14,27,28]$. SCW consumes atmospheric/soil $\mathrm{CO}_{2}$ to produce a net sink of atmospheric $\mathrm{CO}_{2}$ over a geological time scale, and this cannot be neglected in the karst basins [29-31]. In addition, the effects of anthropogenically sourced sulfuric acid and nitric acid are not considered in the common method of using hydrochemical compositions and runoff for the estimation of the karst carbon sink [6], and general studies only considered the effects of a single strong acid (sulfuric acid or nitric acid), which would affect the assessment accuracy of the $\mathrm{CO}_{2}$ consumption related to CCW.

To accurately determine the compound influence of sulfuric acid and nitric acid resulting from human activities on the chemical weathering of carbonate basins and the riverine carbonate system, hydrogeochemical parameters of the surface runoff were investigated in the Lianjiang River Basin (LRB), which is in north of the Pearl River Delta (PRD) of China and under the dual influence of acidic gases transported from the PRD and the industrial regions in north of the Nanling Mountains. The main objectives were as follows: (1) to identify the hydrochemical characteristics of the Lianjiang River (LR) and the main sources of river dissolved loads; (2) to quantify the contribution proportion of SCW and CCW with different dissolution media to riverine DIC; (3) to evaluate the deficit proportion of $\mathrm{CO}_{2}$ consumption caused by nitric acid and sulfuric acid weathering; and (4) to explicate the response characteristics of the riverine carbonate system to human activities.

\section{Materials and Methods}

\subsection{Study Area}

The LRB $\left(112^{\circ} 10^{\prime} \mathrm{E}-113^{\circ} 18^{\prime} \mathrm{E}, 24^{\circ} 09^{\prime} \mathrm{N}-25^{\circ} 07^{\prime} \mathrm{N}\right)$ is located in the north of Guangdong Province, South China and at the southern edge of the important geographic and climatic dividing line, in the Nanling Mountains, East Asia. The LR belongs to the Pearl River Basin from the perspective of hydrology, and is located near the watershed between the Pearl River Basin and the Yangtze River Basin (Figure 1), with a mesoscale drainage area of $10,061 \mathrm{~km}^{2}$. The south end of the LRB is close to the Tropic of Cancer, and the climate type is a typical subtropical monsoon climate, with a humid climate, abundant rainfall between 1400 and $2200 \mathrm{~mm}$ (with an average of $1770 \mathrm{~mm}$ ), and an average annual temperature of $19-20{ }^{\circ} \mathrm{C}$. Most of the precipitation is observed from April to June, accounting for about $45-50 \%$ of rainfall throughout the whole year. After flowing from the headwater for $275 \mathrm{~km}$, the LR flows into the Beijiang River at Jiangkouju, with an average gradient of $0.77 \%$, and constitutes the largest tributary of the Beijiang River in the Pearl River System. The LR system belongs to the trellis drainage, extending from the northwest to the southeast of the drainage basin, and shows typical characteristics of a mountainous river. The main tributaries of the LR flow from the mountains at the edge of the drainage basin to the main stream (Table 1 ). The average annual runoff of the mainstream is $1.2 \times 10^{10} \mathrm{~m}^{3}$ and mainly observed from March to August, accounting for about $70 \%$ of the total runoff. 


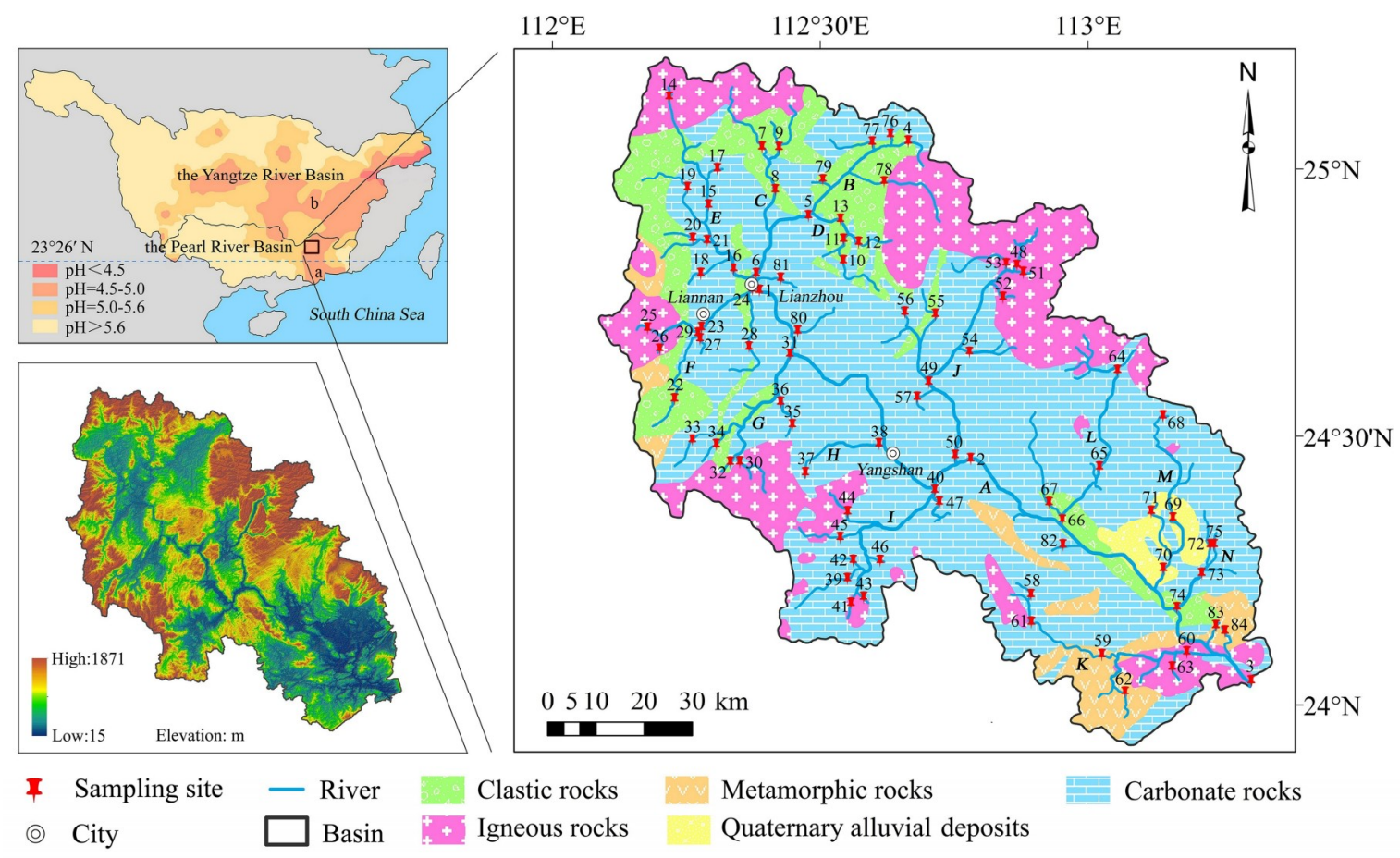

Figure 1. Characteristics of location, sampling sites, river system, geological background, terrains and rainfall $\mathrm{pH}$ in the LRB. Nos. 1-84 stand for the serial number of 84 sampling sites distributed in the Lianjiang River System. A-N stand for the mainstream and main tributaries of the LR: mainstream of the LR (A), the Xingzihe River (B, XZHR), the Baoanhe River (C, BAHR), the Chaotianhe River (D, CTHR), the Dongbeihe River (E, DBHR), the Sanjiangshui River (F, SJSR), the Dongguanshui River (G, DGSR), the Guanbeihe River (H, GBHR), the Qigonghe River (I, QGHR), the Qinglianshui River (J, QLSR), the Shuibianhe River (K, SBHR), the Datanhe River (L, DTHR), the Jintanhe River (M, JTHR), and the Zhutianhe River (N, ZTHR). The Pearl River Delta and the industrial districts in north of the Nanling Mountains are represented as lowercase letters $a$ and $b$, given in the upper left figure. 
Table 1. Main physical and chemical parameters of the LR water in January 2018.

\begin{tabular}{|c|c|c|c|c|c|c|c|c|c|c|c|c|c|c|c|c|c|}
\hline \multirow{2}{*}{ Catchment } & \multirow{2}{*}{$\begin{array}{c}\text { Sample } \\
\text { No. }\end{array}$} & \multirow{2}{*}{$\mathrm{T}\left({ }^{\circ} \mathrm{C}\right)$} & \multirow{2}{*}{$\mathrm{pH}$} & \multirow{2}{*}{$\begin{array}{c}\text { TDS } \\
\left(\mathrm{mg} \cdot \mathrm{L}^{-1}\right)\end{array}$} & \multirow{2}{*}{$\frac{\mathrm{Ca}^{2+}}{(\mu \mathrm{M})^{\mathrm{a}}}$} & \multirow{2}{*}{$\begin{array}{l}\mathrm{Mg}^{2+} \\
(\mu \mathrm{M})\end{array}$} & \multirow{2}{*}{$\begin{array}{l}\mathrm{Na}^{+} \\
(\mu \mathrm{M})\end{array}$} & \multirow{2}{*}{$\frac{\mathrm{K}^{+}}{(\mu \mathrm{M})}$} & \multirow{2}{*}{$\frac{\mathrm{HCO}_{3}{ }^{-}}{(\mu \mathrm{M})}$} & \multirow{2}{*}{$\frac{\mathrm{Cl}^{-}}{(\mu \mathrm{M})}$} & \multirow{2}{*}{$\begin{array}{c}\mathrm{SO}_{4}^{2-} \\
(\mu \mathrm{M})\end{array}$} & \multirow{2}{*}{$\frac{\mathrm{NO}_{3}^{-}}{(\mu \mathrm{M})}$} & \multirow{2}{*}{$\frac{D S i}{(\mu \mathrm{M})}$} & \multirow{2}{*}{$\frac{\mathrm{TZ}^{+}}{(\mu \mathrm{Eq})^{\mathrm{a}}}$} & \multirow{2}{*}{$\frac{\mathrm{TZ}^{-}}{(\mu \mathrm{Eq})}$} & \multirow{2}{*}{$\begin{array}{l}\text { NICB } \\
(\%)\end{array}$} & \multirow{2}{*}{ Location $b$} \\
\hline & & & & & & & & & & & & & & & & & \\
\hline \multirow[t]{3}{*}{ LR } & 1 & 15.2 & 7.9 & 138 & 780 & 155 & 280 & 65 & 1660 & 107 & 153 & 53 & 86 & 2214 & 2126 & 3.97 & ML \\
\hline & 2 & 16.4 & 8.18 & 150 & 960 & 190 & 184 & 62 & 2206 & 87 & 131 & 100 & 121 & 2547 & 2656 & -4.26 & ML \\
\hline & 3 & 15.6 & 7.75 & 142 & 840 & 167 & 285 & 78 & 1580 & 141 & 166 & 92 & 127 & 2377 & 2144 & 9.80 & ML \\
\hline \multirow[t]{3}{*}{ XZHR } & 4 & 9.3 & 7.89 & 76 & 513 & 53 & 77 & 25 & 1020 & 39 & 52 & 47 & 130 & 1233 & 1210 & 1.83 & ML \\
\hline & 5 & 13.5 & 7.97 & 128 & 853 & 162 & 129 & 50 & 1652 & 54 & 125 & 40 & 86 & 2207 & 1996 & 9.57 & ML \\
\hline & 6 & 15 & 8.1 & 130 & 803 & 154 & 160 & 57 & 1696 & 90 & 113 & 42 & 67 & 2130 & 2053 & 3.64 & ML \\
\hline \multirow[t]{3}{*}{ BAHR } & 7 & 11.6 & 7.77 & 75 & 433 & 111 & 98 & 26 & 1062 & 42 & 42 & 18 & 110 & 1211 & 1206 & 0.45 & UT \\
\hline & 8 & 12.4 & 7.71 & 39 & 182 & 54 & 87 & 24 & 484 & 39 & 35 & 35 & 105 & 583 & 630 & -8.04 & MT \\
\hline & 9 & 11.2 & 7.36 & 45 & 184 & 57 & 104 & 27 & 474 & 45 & 38 & 31 & 125 & 611 & 625 & -2.18 & UT \\
\hline CTHR & 10 & 11.8 & 8 & 241 & 1540 & 483 & 94 & 43 & 3402 & 110 & 105 & 105 & 100 & 4184 & 3827 & 8.53 & UT \\
\hline & 11 & 10.2 & 8.05 & 236 & 1505 & 438 & 160 & 71 & 3179 & 146 & 173 & 76 & 100 & 4115 & 3747 & 8.95 & MT \\
\hline & 12 & 10.1 & 8.1 & 194 & 1285 & 306 & 413 & 123 & 2679 & 96 & 116 & 32 & 134 & 3718 & 3038 & 18.29 & DT \\
\hline & 13 & 10.2 & 8.08 & 161 & 1250 & 115 & 170 & 45 & 2346 & 54 & 73 & 18 & 194 & 2944 & 2563 & 12.94 & UT \\
\hline DBHR & 14 & 9.4 & 7.82 & 41 & 155 & 20 & 217 & 54 & 417 & 39 & 31 & 77 & 188 & 620 & 597 & 3.78 & UT \\
\hline & 15 & 11.8 & 7.86 & 110 & 655 & 123 & 196 & 77 & 1391 & 101 & 82 & 68 & 112 & 1829 & 1725 & 5.68 & MT \\
\hline & 16 & 15.1 & 8.42 & 122 & 765 & 134 & 197 & 69 & 1511 & 99 & 116 & 66 & 103 & 2064 & 1907 & 7.57 & DT \\
\hline & 17 & 11.6 & 7.97 & 197 & 1303 & 307 & 183 & 117 & 2608 & 115 & 101 & 144 & 125 & 3519 & 3069 & 12.79 & MT \\
\hline & 18 & 11.2 & 7.68 & 28 & 109 & 66 & 73 & 14 & 295 & 21 & 38 & 24 & 120 & 436 & 416 & 4.42 & UT \\
\hline & 19 & 11.7 & 7.78 & 114 & 628 & 128 & 190 & 53 & 1100 & 68 & 213 & 69 & 146 & 1753 & 1662 & 5.21 & MT \\
\hline & 20 & 13.3 & 7.45 & 38 & 106 & 135 & 77 & 13 & 374 & 45 & 77 & 19 & 121 & 572 & 593 & -3.58 & UT \\
\hline & 21 & 11.9 & 7.72 & 27 & 96 & 79 & 67 & 13 & 328 & 13 & 31 & 12 & 123 & 429 & 415 & 3.32 & MT \\
\hline SJSR & 22 & 12.4 & 7.72 & 26 & 102 & 57 & 73 & 9 & 257 & 22 & 42 & 27 & 108 & 398 & 390 & 2.19 & UT \\
\hline & 23 & 13.2 & 7.69 & 39 & 189 & 71 & 99 & 17 & 497 & 34 & 51 & 29 & 109 & 636 & 662 & -4.09 & MT \\
\hline & 24 & 15.8 & 7.83 & 155 & 895 & 219 & 321 & 78 & 1848 & 206 & 132 & 65 & 166 & 2627 & 2383 & 9.28 & DT \\
\hline & 25 & 12.1 & 7.53 & 46 & 152 & 45 & 232 & 59 & 468 & 65 & 36 & 74 & 304 & 686 & 680 & 0.85 & UT \\
\hline & 26 & 11.8 & 7.5 & 29 & 78 & 27 & 188 & 46 & 290 & 28 & 31 & 33 & 318 & 444 & 412 & 7.23 & UT \\
\hline & 27 & 17.2 & 7.84 & 194 & 1363 & 265 & 87 & 42 & 2779 & 68 & 77 & 95 & 103 & 3383 & 3096 & 8.48 & UT \\
\hline & 28 & 12.2 & 7.95 & 358 & 2185 & 479 & 362 & 216 & 2395 & 293 & 1123 & 419 & 125 & 5906 & 5353 & 9.36 & UT \\
\hline & 29 & 13.3 & 7.76 & 32 & 145 & 68 & 71 & 12 & 371 & 20 & 42 & 19 & 94 & 510 & 494 & 3.11 & MT \\
\hline DGSR & 30 & 11.8 & 7.78 & 38 & 213 & 29 & 107 & 33 & 430 & 34 & 38 & 53 & 195 & 623 & 592 & 4.96 & UT \\
\hline & 31 & 13.4 & 7.88 & 132 & 780 & 169 & 238 & 55 & 1641 & 121 & 123 & 65 & 118 & 2190 & 2073 & 5.38 & DT \\
\hline & 32 & 11.6 & 7.59 & 23 & 96 & 23 & 100 & 32 & 262 & 21 & 21 & 41 & 210 & 370 & 366 & 1.05 & UT \\
\hline & 33 & 14 & 7.94 & 82 & 498 & 93 & 75 & 22 & 1102 & 51 & 42 & 71 & 103 & 1278 & 1307 & -2.23 & UT \\
\hline & 34 & 13 & 8.05 & 115 & 683 & 141 & 74 & 41 & 1359 & 42 & 100 & 60 & 166 & 1763 & 1660 & 5.81 & UT \\
\hline & 35 & 11.9 & 8.15 & 119 & 708 & 227 & 98 & 48 & 1429 & 56 & 150 & 87 & 201 & 2014 & 1873 & 7.01 & UT \\
\hline & 36 & 12.6 & 7.99 & 189 & 1213 & 343 & 150 & 86 & 2377 & 144 & 200 & 111 & 160 & 3345 & 3032 & 9.38 & MT \\
\hline
\end{tabular}


Table 1. Cont.

\begin{tabular}{|c|c|c|c|c|c|c|c|c|c|c|c|c|c|c|c|c|c|}
\hline \multirow{2}{*}{ Catchment } & \multirow{2}{*}{$\begin{array}{l}\text { Sample } \\
\text { No. }\end{array}$} & \multirow{2}{*}{$\mathrm{T}\left({ }^{\circ} \mathrm{C}\right)$} & \multirow{2}{*}{$\mathrm{pH}$} & \multirow{2}{*}{$\begin{array}{c}\text { TDS } \\
\left(\mathrm{mg} \cdot \mathrm{L}^{-1}\right)\end{array}$} & \multirow{2}{*}{$\begin{array}{c}\mathrm{Ca}^{2+} \\
(\mu \mathrm{M})^{a} \\
\end{array}$} & \multirow{2}{*}{$\begin{array}{l}\mathrm{Mg}^{2+} \\
(\mu \mathrm{M}) \\
\end{array}$} & \multirow{2}{*}{$\begin{array}{l}\mathrm{Na}^{+} \\
(\mu \mathrm{M}) \\
\end{array}$} & \multirow{2}{*}{$\begin{array}{c}\mathrm{K}^{+} \\
(\mu \mathrm{M})\end{array}$} & \multirow{2}{*}{$\begin{array}{c}\mathrm{HCO}_{3}{ }^{-} \\
(\mu \mathrm{M})\end{array}$} & \multirow{2}{*}{$\begin{array}{c}\mathrm{Cl}^{-} \\
(\mu \mathrm{M}) \\
\end{array}$} & \multirow{2}{*}{$\begin{array}{c}\mathrm{SO}_{4}{ }^{2-} \\
(\mu \mathrm{M})\end{array}$} & \multirow{2}{*}{$\begin{array}{r}\mathrm{NO}_{3}{ }^{-} \\
(\mu \mathrm{M})\end{array}$} & \multirow{2}{*}{$\begin{array}{c}\text { DSi } \\
(\mu \mathrm{M})\end{array}$} & \multirow{2}{*}{$\frac{\mathrm{TZ}^{+}}{(\mu \mathrm{Eq})^{\mathrm{a}}}$} & \multirow{2}{*}{$\frac{\mathrm{TZ}^{-}}{(\mu \mathrm{Eq})}$} & \multirow{2}{*}{$\begin{array}{l}\text { NICB } \\
(\%)\end{array}$} & \multirow{2}{*}{ Location $b$} \\
\hline & & & & & & & & & & & & & & & & & \\
\hline \multirow[t]{2}{*}{ GBHR } & 37 & 11.1 & 7.85 & 35 & 208 & 48 & 83 & 28 & 499 & 25 & 25 & 39 & 174 & 622 & 613 & 1.48 & UT \\
\hline & 38 & 17.1 & 8.61 & 150 & 915 & 327 & 75 & 30 & 2216 & 42 & 64 & 29 & 133 & 2589 & 2415 & 6.72 & DT \\
\hline \multirow[t]{9}{*}{ QGHR } & 39 & 15 & 7.52 & 216 & 1573 & 142 & 70 & 79 & 2638 & 99 & 125 & 84 & 124 & 3578 & 3071 & 14.18 & UT \\
\hline & 40 & 17 & 7.78 & 193 & 1288 & 261 & 172 & 82 & 2251 & 107 & 181 & 260 & 160 & 3352 & 2980 & 11.09 & DT \\
\hline & 41 & 18.1 & 7.78 & 225 & 1683 & 234 & 39 & 16 & 3400 & 56 & 60 & 65 & 85 & 3888 & 3642 & 6.34 & UT \\
\hline & 42 & 14.2 & 8.06 & 121 & 853 & 85 & 63 & 48 & 1525 & 51 & 122 & 47 & 166 & 1986 & 1866 & 6.01 & UT \\
\hline & 43 & 14 & 8.11 & 146 & 978 & 180 & 87 & 51 & 2141 & 54 & 45 & 56 & 139 & 2452 & 2341 & 4.54 & UT \\
\hline & 44 & 11.6 & 7.75 & 44 & 185 & 38 & 169 & 56 & 511 & 56 & 33 & 47 & 219 & 672 & 681 & -1.43 & UT \\
\hline & 45 & 13.6 & 7.94 & 74 & 283 & 49 & 88 & 37 & 590 & 48 & 45 & 74 & 161 & 788 & 801 & -1.71 & UT \\
\hline & 46 & 14.3 & 7.92 & 225 & 1280 & 283 & 142 & 212 & 2242 & 163 & 173 & 316 & 119 & 3479 & 3068 & 11.82 & UT \\
\hline & 47 & 19.1 & 8.03 & 212 & 1695 & 135 & 48 & 14 & 3188 & 70 & 59 & 44 & 79 & 3723 & 3421 & 8.12 & UT \\
\hline \multirow[t]{10}{*}{ QLSR } & 48 & 14.3 & 7.48 & 31 & 118 & 11 & 215 & 37 & 385 & 14 & 20 & 21 & 310 & 510 & 460 & 9.77 & UT \\
\hline & 49 & 15.7 & 7.99 & 102 & 673 & 95 & 112 & 30 & 1445 & 34 & 55 & 37 & 132 & 1676 & 1626 & 2.96 & MT \\
\hline & 50 & 16.8 & 8.13 & 161 & 950 & 137 & 120 & 59 & 1921 & 76 & 93 & 40 & 117 & 2354 & 2223 & 5.56 & DT \\
\hline & 51 & 14.6 & 7.47 & 26 & 88 & 10 & 190 & 23 & 315 & 11 & 14 & 43 & 334 & 408 & 398 & 2.61 & UT \\
\hline & 52 & 17.4 & 7.32 & 42 & 173 & 18 & 234 & 47 & 534 & 37 & 23 & 58 & 301 & 662 & 674 & -1.88 & UT \\
\hline & 53 & 14.5 & 8.07 & 121 & 758 & 143 & 122 & 55 & 1593 & 42 & 110 & 37 & 187 & 1978 & 1893 & 4.31 & UT \\
\hline & 54 & 17.6 & 8.36 & 152 & 1213 & 140 & 94 & 19 & 2284 & 45 & 49 & 44 & 139 & 2817 & 2470 & 12.30 & MT \\
\hline & 55 & 15.1 & 8.06 & 151 & 1138 & 117 & 114 & 42 & 2216 & 62 & 46 & 65 & 169 & 2665 & 2435 & 8.64 & UT \\
\hline & 56 & 15.5 & 8.55 & 221 & 1740 & 309 & 85 & 53 & 3385 & 79 & 106 & 66 & 168 & 4236 & 3743 & 11.65 & UT \\
\hline & 57 & 17.5 & 7.82 & 245 & 1798 & 192 & 102 & 64 & 3398 & 144 & 139 & 53 & 56 & 4144 & 3872 & 6.56 & UT \\
\hline \multirow[t]{6}{*}{ SBHR } & 58 & 13.6 & 7.88 & 172 & 1180 & 131 & 97 & 123 & 2084 & 144 & 103 & 200 & 129 & 2842 & 2634 & 7.33 & UT \\
\hline & 59 & 13.9 & 7.78 & 164 & 588 & 124 & 139 & 104 & 1157 & 118 & 95 & 95 & 118 & 1665 & 1560 & 6.33 & MT \\
\hline & 60 & 13.6 & 7.64 & 89 & 475 & 100 & 230 & 75 & 1099 & 79 & 70 & 74 & 149 & 1454 & 1391 & 4.32 & DT \\
\hline & 61 & 14.1 & 7.79 & 160 & 1055 & 122 & 122 & 139 & 1858 & 175 & 107 & 179 & 147 & 2615 & 2426 & 7.23 & UT \\
\hline & 62 & 13.4 & 7.44 & 23 & 69 & 39 & 69 & 41 & 253 & 29 & 16 & 28 & 154 & 326 & 342 & -4.78 & UT \\
\hline & 63 & 11.6 & 7.36 & 31 & 103 & 29 & 85 & 81 & 234 & 45 & 38 & 72 & 188 & 430 & 426 & 0.85 & UT \\
\hline DTHR & 64 & 15.2 & 7.74 & 124 & 720 & 250 & 128 & 44 & 1865 & 39 & 31 & 68 & 203 & 2113 & 2035 & 3.70 & UT \\
\hline & 65 & 16.6 & 7.85 & 156 & 1220 & 147 & 122 & 45 & 2364 & 51 & 67 & 56 & 159 & 2902 & 2604 & 10.25 & MT \\
\hline & 66 & 17 & 8.21 & 145 & 1053 & 169 & 125 & 51 & 2118 & 51 & 75 & 40 & 109 & 2619 & 2359 & 9.92 & DT \\
\hline & 67 & 17.5 & 7.99 & 220 & 1723 & 275 & 75 & 52 & 3178 & 110 & 109 & 65 & 57 & 4122 & 3571 & 13.36 & MT \\
\hline JTHR & 68 & 15.2 & 6.99 & 38 & 216 & 50 & 34 & 33 & 379 & 56 & 55 & 100 & 56 & 598 & 646 & -7.98 & UT \\
\hline & 69 & 18.1 & 7.2 & 82 & 515 & 75 & 44 & 37 & 759 & 76 & 141 & 98 & 86 & 1260 & 1215 & 3.62 & MT \\
\hline & 70 & 18.5 & 7.65 & 198 & 1385 & 224 & 86 & 82 & 2526 & 158 & 146 & 121 & 99 & 3387 & 3096 & 8.57 & DT \\
\hline & 71 & 17.1 & 7.79 & 192 & 1470 & 152 & 69 & 67 & 2559 & 85 & 140 & 71 & 80 & 3380 & 2994 & 11.44 & UT \\
\hline
\end{tabular}


Table 1. Cont.

\begin{tabular}{|c|c|c|c|c|c|c|c|c|c|c|c|c|c|c|c|c|c|}
\hline \multirow{2}{*}{ Catchment } & \multirow{2}{*}{$\begin{array}{c}\text { Sample } \\
\text { No. }\end{array}$} & \multirow{2}{*}{$\mathrm{T}\left({ }^{\circ} \mathrm{C}\right)$} & \multirow{2}{*}{$\mathrm{pH}$} & \multirow{2}{*}{$\begin{array}{c}\text { TDS } \\
\left(\mathrm{mg} \cdot \mathrm{L}^{-1}\right)\end{array}$} & \multirow{2}{*}{$\frac{\mathrm{Ca}^{2+}}{(\mu \mathrm{M})^{a}}$} & \multirow{2}{*}{$\begin{array}{l}\mathrm{Mg}^{2+} \\
(\mu \mathrm{M}) \\
\end{array}$} & \multirow{2}{*}{$\begin{array}{l}\mathrm{Na}^{+} \\
(\mu \mathrm{M})\end{array}$} & \multirow{2}{*}{$\begin{array}{c}\mathrm{K}^{+} \\
(\mu \mathrm{M}) \\
\end{array}$} & \multirow{2}{*}{$\begin{array}{l}\mathrm{HCO}_{3}{ }^{-} \\
(\mu \mathrm{M})\end{array}$} & \multirow{2}{*}{$\frac{\mathrm{Cl}^{-}}{(\mu \mathrm{M})}$} & \multirow{2}{*}{$\begin{array}{c}\mathrm{SO}_{4}{ }^{2-} \\
(\mu \mathrm{M})\end{array}$} & \multirow{2}{*}{$\begin{array}{c}\mathrm{NO}_{3}^{-} \\
(\mu \mathrm{M})\end{array}$} & \multirow{2}{*}{$\frac{D S i}{(\mu \mathrm{M})}$} & \multirow{2}{*}{$\frac{\mathrm{TZ}^{+}}{(\mu \mathrm{Eq})^{\mathrm{a}}}$} & \multirow{2}{*}{$\frac{\mathrm{TZ}^{-}}{(\mu \mathrm{Eq})}$} & \multirow{2}{*}{$\begin{array}{l}\text { NICB } \\
(\%)\end{array}$} & \multirow{2}{*}{ Location $b$} \\
\hline & & & & & & & & & & & & & & & & & \\
\hline \multirow[t]{4}{*}{ ZTHR } & 72 & 20.5 & 9.02 & 120 & 768 & 133 & 69 & 46 & 1488 & 121 & 76 & 63 & 90 & 1916 & 1824 & 4.77 & UT \\
\hline & 73 & 16.6 & 7.77 & 243 & 1675 & 194 & 230 & 143 & 3057 & 262 & 96 & 202 & 89 & 4111 & 3712 & 9.71 & MT \\
\hline & 74 & 16.4 & 7.26 & 60 & 353 & 62 & 42 & 29 & 643 & 48 & 61 & 69 & 63 & 899 & 883 & 1.83 & DT \\
\hline & 75 & 16.5 & 7.22 & 53 & 206 & 50 & 31 & 25 & 358 & 42 & 54 & 60 & 62 & 568 & 568 & -0.09 & UT \\
\hline Small & 76 & 11.4 & 8.09 & 267 & 1978 & 207 & 70 & 64 & 3478 & 65 & 293 & 50 & 114 & 4502 & 4179 & 7.19 & ST \\
\hline \multirow[t]{8}{*}{ tributaries } & 77 & 11.2 & 8.24 & 293 & 2020 & 521 & 131 & 57 & 4199 & 113 & 142 & 92 & 87 & 5270 & 4687 & 11.06 & ST \\
\hline & 78 & 10.9 & 7.51 & 25 & 138 & 11 & 65 & 24 & 301 & 17 & 20 & 15 & 40 & 387 & 373 & 3.38 & MT \\
\hline & 79 & 16.3 & 7.62 & 315 & 2243 & 351 & 176 & 84 & 4530 & 141 & 120 & 100 & 171 & 5446 & 5010 & 8.01 & ST \\
\hline & 80 & 18 & 7.9 & 332 & 1890 & 925 & 77 & 48 & 4814 & 73 & 169 & 97 & 56 & 5755 & 5322 & 7.52 & ST \\
\hline & 81 & 17.9 & 7.54 & 303 & 2098 & 402 & 89 & 40 & 4337 & 87 & 144 & 102 & 141 & 5128 & 4813 & 6.13 & ST \\
\hline & 82 & 20.1 & 7.47 & 281 & 1705 & 504 & 92 & 58 & 1837 & 101 & 1115 & 48 & 119 & 4568 & 4216 & 7.71 & ST \\
\hline & 83 & 15.4 & 7.63 & 51 & 228 & 100 & 111 & 32 & 546 & 37 & 92 & 23 & 160 & 798 & 788 & 1.22 & ST \\
\hline & 84 & 15.9 & 6.79 & 32 & 110 & 67 & 106 & 43 & 388 & 35 & 27 & 8 & 207 & 502 & 485 & 3.51 & ST \\
\hline
\end{tabular}

a $\mu \mathrm{mol} \cdot \mathrm{L}^{-1}$ and $\mu \mathrm{eq} \cdot \mathrm{L}^{-1}$ are expressed as $\mu \mathrm{M}$ and $\mu \mathrm{Eq}$, respectively; ${ }^{\mathrm{b}}$ Abbreviations of ML, UT, MT, DT and ST stand for the mainstream, upstream of tributaries, mid-stream of tributaries, downstream of tributaries and small tributaries of the LR, respectively. 
The LRB is located in the east border of the boundary between the Yangtze Block and the Cathaysian Block, from the geological perspective [32], and is distributed in the top and west limb parts of the frontal arc in the Northern Guangdong $\varepsilon$-type Tectonic System (a complete example of the $\varepsilon$-type Tectonic System in China) [33]. A large area of Carboniferous-Triassic limestone, dolomite and dolomitic limestone are outcropped in the central section of the LRB, which is characterized as a shallow marine carbonate formation and in which the limestone area accounts for more than $60 \%$ of the total basin area. There are Sinian metamorphic volcanic rocks, siliceous rocks and shales; Cambrian quartz sandstone and sandy shales; and Devonian purple and brown sandy shales distributed in the margin of upstream and mid-stream regions. In the former, the mineral composition is mainly potassium-sodium silicate, and there is a small amount of carbonate minerals, such as calcite and dolomite, in addition to silicate minerals in the latter. The Ordovician and Silurian strata in the LRB are missing, and the Jurassic and Cretaceous strata are scattered. A small fraction of Quaternary continental alluvial deposits and metamorphic rocks are observed in lower reaches (Figure 1). The terrains of the LRB are higher in the northwest and lower in the southeast with the main landform of karst plateau and basin. High mountains are distributed in the north and west, and karst basins and hilly areas are in the southeast. The karst plateau of the LRB is the eastern extension part of the karst area in Southwest China, which is one of the three largest concentrated karst areas in the world as well as the typical ecological vulnerable zone. The LRB is dominated by calcareous soil, which has developed as a consequence of the dissolution of carbonate rocks and was followed by red soil. There are numerous types of vegetation, including coniferous forests, evergreen broad-leaved forests, deciduous broad-leaved forests, mixed forests, bamboo forests and shrubs. Several cities, such as Lianzhou, Liannan, and Yangshan, are distributed in the upper and middle reaches of the mainstream (Figure 1). The upper reaches of the main tributaries are sparsely populated, yet the lower reaches are densely populated. Forest land accounts for the largest proportion of the drainage area (42\%), and cultivated land accounts for about $10 \%$.

The northern part of Guangdong Province has been seriously polluted by acid rain, and it has been a heavily acidic rain area $(4.5 \leq \mathrm{pH}<5.0$ and acid rain frequency $>50 \%$, Figure 1$)$ in recent years [34]. In addition to local pollutant gas emissions, acid rain in the LRB is also relevant to the long-distance transmission of pollutants, such as $\mathrm{SO}_{2}$ and $\mathrm{NO}_{\mathrm{x}}$ from industrial activities of the economically developed PRD and the industrial districts in north of the Nanling Mountains [35]. Rainfall events in the LRB are generally affected by the Quasi-stationary Front of South China, which is the main weather system regulating the rainfall in South China in winter and frequently stagnates between $22^{\circ}$ and $25^{\circ} \mathrm{N}$ [36]. It can easily form acid rain in rainfall events under the condition that acid substances are washed away by rainwater. The $\mathrm{pH}$ of acid rain in summer is higher than that in winter because of the large amount of rainfall from typhoons, which result in a high $\mathrm{pH}$ and low frequency of acid rain [37]. Except for acid precipitation, local human activities, such as industrial and agricultural activities, will also affect the biogeochemical cycle in the drainage basin. It also deserves to be mentioned that biogeochemical processes in winter in the LRB proceed as usual because there are no hydrological freezing phenomena in the LR in January, which is annually the coldest month.

\subsection{Sampling and Measurements}

To fully understand the impact of human activities on the chemical weathering processes and riverine carbonate system in the LRB, 84 sampling sites in the mainstream and tributaries (including tertiary tributaries in headwater areas) were selected and sampled from 2 January to 8 January 2018. All of the water samples were collected in or near the middle channel of each river/stream, obviously avoiding pollution. Polyethylene sample bottles were fully rinsed using river water near the sampling sites more than three times before sampling and filled with river water ensuring that no air bubbles remain in the bottles. Samples were brought back to the laboratory as soon as possible and refrigerated at $4{ }^{\circ} \mathrm{C}$. Alkalinity titration, ion content analysis and other measurements were completed within $48 \mathrm{~h}$ after sampling. The water temperature (T), pH and total dissolved solids (TDS) were tested in situ 
using an Ultrameter ${ }^{\mathrm{TM}} 6 \mathrm{P}$ portable conductivity meter (Myron $\mathrm{L}^{\circledR}$ Company, Carlsbad, CA, USA), with a test accuracy of $\pm 0.10^{\circ} \mathrm{C}, \pm 0.01$ and $0.01 \mathrm{mg} \cdot \mathrm{L}^{-1}$, respectively. The probe was calibrated before sampling and calibrated once during the sampling period according to the instructions.

Every water sample was divided into two parts. One part was filtered through a Whatman GF/F filter (GE Healthcare, Boston, MA, USA) (with a pore size of $0.45 \mu \mathrm{m}$ ), then used to determine the main cations and anions $\left(\mathrm{K}^{+}, \mathrm{Na}^{+}, \mathrm{Ca}^{2+}, \mathrm{Mg}^{2+}, \mathrm{Cl}^{-}, \mathrm{NO}_{3}{ }^{-}\right.$, and $\mathrm{SO}_{4}{ }^{2-}$ ) and dissolved silicon (expressed as DSi in this study). Samples for cations were acidified to $\mathrm{pH}<2$ with $\mathrm{HNO}_{3}$. The cations and DSi were measured using an IRIS (HR) type Inductively Coupled Plasma-Atomic Emission Spectrometric (ICP-AES, manufactured by TJA, Boston, MA, USA), and anions $\left(\mathrm{Cl}^{-}, \mathrm{NO}^{3-}, \mathrm{SO}_{4}{ }^{2-}\right)$ were measured with ICS-900 Ion Chromatography, and the test accuracies were greater than $0.5 \%$. The remaining unfiltered part of the sample was titrated to determine the total alkalinity (Alk.), according to Gran [38], with a Titralab-865 automatic titrator from the Hach Company (Loveland, CO, USA), the experimental error of which was less than $5 \%$. Before titration, the $\mathrm{pH}$ meter was calibrated with the particular buffer solutions (with $\mathrm{pH}$ values of $4.005,7.000$ and 10.012). Using the titrant $\left(\mathrm{HCl}, 0.05 \mathrm{~mol} \cdot \mathrm{L}^{-1}\right)$, the filtrated sample $(100 \mathrm{~mL})$ was then taken and titrated to $\mathrm{pH}=4.5,4.2,3.8$ and 3.5 , and the corresponding $\mathrm{HCl}$ volumes were recorded. The final titration point was controlled by a glass electrode in the titration process [38]. Each sample was titrated 3 times, and the sample alkalinity was calculated by the Graphics of Gran. The total alkalinity was approximately equal to the concentration of $\mathrm{HCO}_{3}{ }^{-}$, when the $\mathrm{pH}$ ranged from 6 to 10 in the water sample.

\subsection{Data Processing}

The DEM used in this study came from the digital elevation data of GDEMDEM 30 M resolution from the Geospatial Data Cloud website [39]. The geological map used was based on the "Geological Map of Guangdong Province, Hong Kong and Macao Special Administrative Region" (1:1,750,000), and the drainage system and rock distribution maps were extracted using ArcGIS 10.0 (Environmental Systems Research Institute, Inc., Redlands, CA, USA). IBM SPSS Statistics 19.0 (IBM, Armonk, NY, USA) was used for the data statistics and the Pearson correlation analysis. Graphs were drawn using Grapher 12.0 software (Golden Software, LLC., Golden, CO, USA) and Origin Pro 2018 (OriginLab Corporation, Northampton, MA, USA). The dissolved inorganic carbon (DIC) and partial pressure of carbon dioxide $\left(p \mathrm{CO}_{2}\right)$ were calculated through the CO2SYS based on the $\mathrm{pH}$, water temperature and alkalinity of the water obtained from the sampling and measuring period [2]. The calcite saturation index (SIc) of the river water was calculated through the hydrogeochemical program of WATSPEC15 [28].

\section{Results}

\subsection{Physical and Chemical Parameters}

The hydrochemical compositions of the mainstream and main tributaries in the LR are listed in Table 1. The temperature of the river water samples varies from 9.3 to $20.5{ }^{\circ} \mathrm{C}$, with an average of $14.3^{\circ} \mathrm{C}$ in January 2018. The minimum value appears at the sample 4 in the upper reach of the mainstream, and the maximum value appears in the Zhutianhe River, a tributary in the lower reach of the LR, showing the coupled effects of the southern subtropical monsoon climate and elevation on the water temperature. The range of $\mathrm{pH}$ in the LR varies from 6.79 to 9.02, with an average of 7.82, and most of the water samples are characterized as weakly alkaline, which indicates the dominant effect of the karst water on the $\mathrm{pH}$ of the LR. The variation range of the total dissolved solids (TDS) are from 22.54 to $357.5 \mathrm{mg} \cdot \mathrm{L}^{-1}$, with an average of $131.8 \mathrm{mg} \cdot \mathrm{L}^{-1}$, which is higher than the average of $100 \mathrm{mg} \cdot \mathrm{L}^{-1}$ of most rivers worldwide [3], reflecting that the rock chemical weathering is relatively intense in the LRB.

Equivalent concentrations of total cations $\left(\mathrm{TZ}^{+}=2 \mathrm{Ca}^{2+}+2 \mathrm{Mg}^{2+}+\mathrm{K}^{+}+\mathrm{Na}^{+}\right)$of all samples from the LR are between $326 \mu \mathrm{eq} \cdot \mathrm{L}^{-1}$ and $5906 \mu \mathrm{eq} \cdot \mathrm{L}^{-1}$, with a mean of $2210 \mu \mathrm{eq} \cdot \mathrm{L}^{-1}$, which is higher than the average value of 61 rivers in the world [40]. Equivalent concentrations of total anions 
$\left(\mathrm{TZ}^{-}=\mathrm{HCO}_{3}{ }^{-}+2 \mathrm{SO}_{4}{ }^{2-}+\mathrm{NO}_{3}{ }^{-}+\mathrm{Cl}^{-}\right)$are between 342 and $5353 \mu \mathrm{eq} \cdot \mathrm{L}^{-1}$, with an average of $2041 \mu \mathrm{eq} \cdot \mathrm{L}^{-1}$. The equilibrium state of river water can be reflected by the inorganic charge balance index $\left[\mathrm{NICB}=\left(\mathrm{TZ}^{+}-\mathrm{TZ}^{-}\right) / \mathrm{TZ}^{+} \times 100\right]$. The $\mathrm{NICB}$ of 72 out of the 84 samples are in the range from $-10 \%$ to $10 \%$, which could be explained by the fact that the anions and cations in the LR are generally in equilibrium, and those of the remaining 12 samples $(12,13,17,39,40,46,54,56,65,67,71$, and 77) are not in equilibrium but vary from $10.25 \%$ to $18.29 \%$, which is probably due to the presence of undetected anions, such as organic acids and phosphates, resulting from domestic sewage.

\subsection{Cations and Anions}

To conveniently clarify the hydrochemical type of the LR water and determine the main material sources of the dissolved loads, 84 water samples were categorized into five groups: the mainstream of the LR (ML), upstream of tributaries (UT), mid-stream of tributaries (MT), downstream of tributaries (DT) and small tributaries (ST) (Table 1). Ternary graphs of the main cations and anions in the LR were plotted according to the measured chemical compositions (Figure 2). Cations of the LR in January 2018 are dominated by calcium, accounting for $78.71 \%$ of the total cations, followed by magnesium, sodium and potassium, accounting for $9.35 \%, 6.92 \%$, and $5.03 \%$, respectively. The anions are dominated by bicarbonate, accounting for $84.97 \%$ of the total anions. Sulfate ion is the second largest anion, accounting for $8.98 \%$ of the total cations, followed by nitrate and chloride ions, accounting for $3.78 \%$ and $2.27 \%$, respectively. Therefore, the hydrochemical type of the mainstream and tributaries in the LR belongs to the $\mathrm{HCO}_{3}-\mathrm{Ca}$ type, indicating that the typical karst water characterized by "higher calcium and carbon" dominates the river hydrochemical composition, which is consistent with the geological background, dominated by carbonate rocks in the LRB (Figure 1).
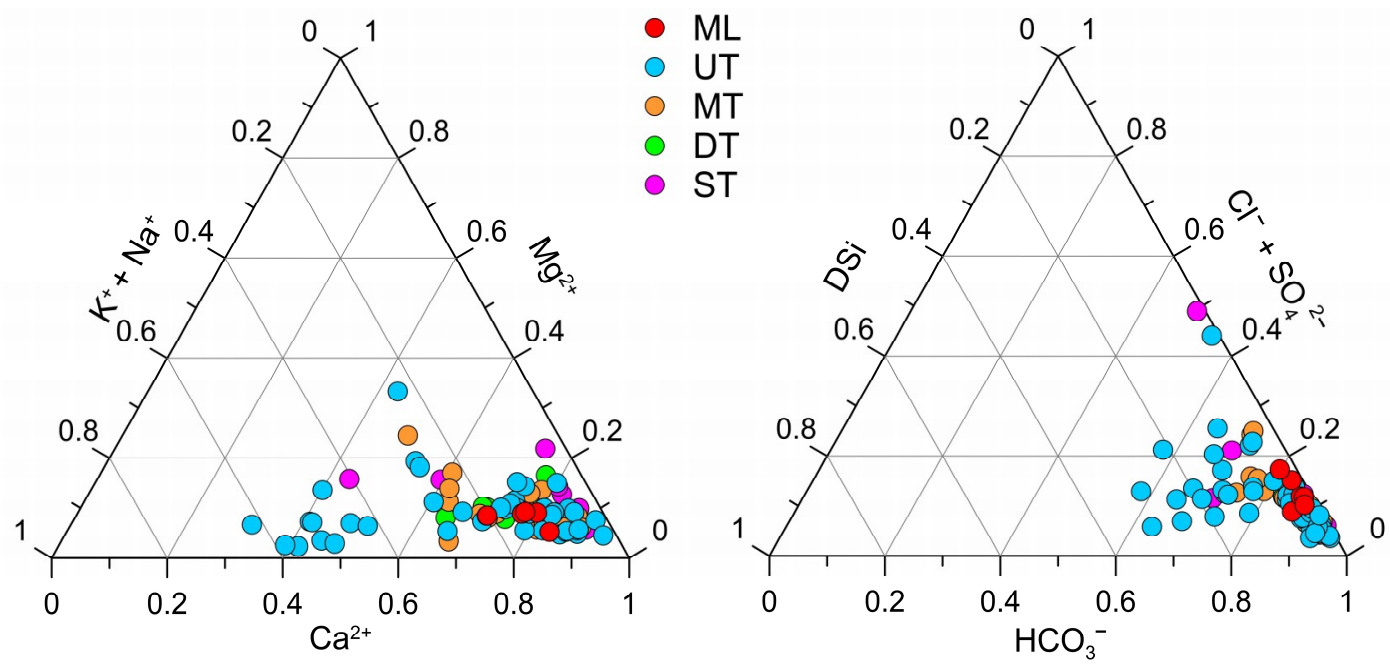

Figure 2. Ternary graphs of cations and anions of the LR in January 2018.

It is worth mentioning that the $\mathrm{SO}_{4}{ }^{2-}$ concentrations of Samples 28 and 82 are higher (1122 and $\left.1114 \mu \mathrm{mol} \cdot \mathrm{L}^{-1}\right)$, accounting for $37.13 \%$ and $47.41 \%$ of the total anions, respectively. In addition, some proportions of $\left(\mathrm{K}^{+}+\mathrm{Na}^{+}\right)$in the upstream of tributaries to the total cations are greater than $40 \%$, and the DSi concentrations vary from 55.71 to $333.57 \mu \mathrm{mol} \cdot \mathrm{L}^{-1}$, with an average of $159.22 \mu \mathrm{mol} \cdot \mathrm{L}^{-1}$ (Table 1), which is slightly higher than the average concentration of DSi in the global rivers $\left(158 \mu \mathrm{mol} \cdot \mathrm{L}^{-1}\right)$ [41]. The DSi concentrations of Samples 25, 26, 48, 51, and 52 (303.93, $317.86,309.64,333.57$ and $301.43 \mu \mathrm{mol} \cdot \mathrm{L}^{-1}$, respectively) are close to that of the Changhuajiang River (376.39 $\left.\mu \mathrm{mol} \cdot \mathrm{L}^{-1}\right)$, a silicate-dominated basin on Hainan Island, China [42], indicating that the chemical compositions in the upstream of tributaries were characterized by the chemical weathering of silicate rocks. 


\subsection{Spatial Patterns of $p \mathrm{CO}_{2}$, SIc and DIC}

The $p \mathrm{CO}_{2}$ in the mainstream of the LR varies from 712 to $1624 \mu \mathrm{atm}$, with an average of $1025 \pm$ $313 \mu \mathrm{atm}$, and those of the main tributaries are all supersaturated, relative to those of the atmosphere (407.54 $\mu \mathrm{atm})$ [43], increasing from upstream to downstream by 1177, 1242 and $1394 \mu \mathrm{atm}$, respectively, which are lower than the average value of global rivers $(2900 \mu \mathrm{atm})$ [44]. The SIc spatial distribution characteristics of tributaries are similar to those of $p \mathrm{CO}_{2}$, and the SIc values from upstream to downstream in tributaries are $-0.74,-0.51$ and -0.03 , respectively, showing an increasing trend from upstream to downstream, which reflects that the calcite saturation state of the river water varies from an unsaturated to a saturated state from upstream to downstream in the main tributaries of the LR. The SIc of the LR mainstream varies from -0.59 to 0.35 , with an average of $-0.11 \pm 0.29$, which is generally considered as a calcite unsaturation state.

The calculated DIC in the mainstream and tributaries vary from 263 to $4982 \mu \mathrm{mol} \cdot \mathrm{L}^{-1}$, with an average of $1740 \mu \mathrm{mol} \cdot \mathrm{L}^{-1} \cdot \mathrm{HCO}_{3}{ }^{-}$is the most abundant dissolved carbonate in river water, and its proportion to DIC varies from $70.24 \%$ to $98.06 \%$, with an average of $94.6 \%$ (Table 2). The DIC contents in tributaries gradually increase from upstream to downstream $(1461,1645$ and $1932 \mu \mathrm{mol} \cdot \mathrm{L}^{-1}$, respectively).

Table 2. Variations and average values for $p \mathrm{CO}_{2}$, SIc, DIC and other parameters in the mainstream and tributaries of the LR.

\begin{tabular}{|c|c|c|c|c|c|c|c|c|}
\hline \multirow{2}{*}{ Parameter } & \multicolumn{2}{|c|}{ ML } & \multicolumn{2}{|c|}{ UT } & \multicolumn{2}{|c|}{ MT } & \multicolumn{2}{|c|}{ DT } \\
\hline & Range & Average & Range & Average & Range & Average & Range & Average \\
\hline $\mathrm{T}\left({ }^{\circ} \mathrm{C}\right)$ & $9.3-16.4$ & $14.2 \pm 2.3$ & $9.4-20.5$ & $13.9 \pm 2.5$ & $10.2-18.1$ & $13.9 \pm 2.5$ & $10.1-18.5$ & $15.5 \pm 2.3$ \\
\hline $\mathrm{EC}\left(\mu \mathrm{S} \cdot \mathrm{cm}^{-1}\right)$ & $116-228$ & $194 \pm 36$ & $35-517$ & $169 \pm 122$ & $38-360$ & $188 \pm 109$ & 94-299 & $220 \pm 61$ \\
\hline $\mathrm{pH}$ & $7.75-8.18$ & $7.97 \pm 0.14$ & $6.99-9.02$ & $7.79 \pm 0.35$ & $7.2-8.36$ & $7.82 \pm 0.24$ & $7.26-8.61$ & $7.95 \pm 0.37$ \\
\hline$p \mathrm{CO}_{2}(\mu \mathrm{atm})$ & $712-1624$ & $1025 \pm 313$ & $88-4609$ & $1177 \pm 930$ & $349-3063$ & $1242 \pm 798$ & $323-3416$ & $1394 \pm 87$ \\
\hline $\mathrm{CO}_{3}{ }^{2-}\left(\mathrm{mg} \cdot \mathrm{L}^{-1}\right)$ & $0.15-0.77$ & $0.37 \pm 0.21$ & $0.01-3.9$ & $0.38 \pm 0.7$ & $0.02-1.22$ & $0.32 \pm 0.32$ & $0.03-2.08$ & $0.57 \pm 0.55$ \\
\hline SIc & $-0.59-0.35$ & $-0.11 \pm 0.29$ & $-2.4-1.09$ & $-0.74 \pm 1.09$ & $-2-0.65$ & $-0.51 \pm 0.9$ & $-1.46-0.75$ & $-0.03 \pm 0.59$ \\
\hline $\mathrm{DIC}(\mu \mathrm{M})$ & $1062-2256$ & $1690 \pm 346$ & $263-3549$ & $1461 \pm 1107$ & $328-3275$ & $1645 \pm 1063$ & $735-2753$ & $1932 \pm 587$ \\
\hline
\end{tabular}

\section{Discussions}

\subsection{Material Sources of River Dissolved Loads}

\subsubsection{Sea Salt Precipitation}

Atmospheric precipitation is the dominant recharge source of the surface runoff in the LRB in the context of a humid subtropical monsoon climate. The distance between the southernmost border of the LRB $\left(113^{\circ} 05^{\prime} 04^{\prime \prime}\right.$ E, $\left.23^{\circ} 55^{\prime} 33^{\prime \prime} N\right)$ and the Pearl River Estuary $\left(113^{\circ} 42^{\prime} 06^{\prime \prime}\right.$ E, $\left.22^{\circ} 37^{\prime} 07^{\prime \prime} N\right)$ is only $158 \mathrm{~km}$. Therefore, the LRB is obviously affected by the warm and humid air mass from the South China Sea and the Western Pacific Ocean, as well as that from the Indian Ocean. $\mathrm{Cl}^{-}$is the main component of rainwater, with a conservative behavior during the water cycle process, and is gradually used as a reference element to estimate the contribution of sea salt precipitation to the river hydrochemical composition [45]. It is generally believed that the cyclic chloride in surface water is mainly derived from sea salt precipitation, evaporite dissolution and human activities (i.e., the common salt in domestic sewage) [46,47].

There are hardly any saline formations but distributes several cities and towns at the intersections of rivers in the LRB. Sample 51, which was collected in a small tributary of the Qinglianshui River flowing through a single lithology (granite) region that is not influenced by salt formation and human activities, has the lowest value of $\mathrm{Cl}^{-}$concentrations $\left(11.27 \mu \mathrm{mol} \cdot \mathrm{L}^{-1}\right)$ of all samples, and it can be assumed that the $\mathrm{Cl}^{-}$of Sample 51 completely originates from sea salt precipitation. Therefore, the $\mathrm{Cl}^{-}$concentration of Sample 51 is used to represent the $\mathrm{Cl}^{-}$concentration in the rainfall of the LRB. Sea salt correction is performed with reference to the concentration ratios of other ions in standard seawater, where $\mathrm{Cl}^{-} / \mathrm{Na}^{+}=1.15, \mathrm{Ca}^{2+} / \mathrm{Na}^{+}=0.02, \mathrm{Mg}^{2+} / \mathrm{Na}^{+}=0.11$, and $\mathrm{HCO}_{3}{ }^{-} / \mathrm{Na}^{+}=0.004[3]$. 
The calculated proportions of sea salt precipitation and human activities to $\mathrm{Cl}^{-}$concentrations are $23.23 \%$ and $76.77 \%$, respectively.

Correlation analysis between ions shows that there is a significant positive correlation between $\mathrm{K}^{+}, \mathrm{Na}^{+}$, and $\mathrm{Cl}^{-}$(Table 3), indicating that there is a consistent source for $\mathrm{K}^{+}, \mathrm{Na}^{+}$and $\mathrm{Cl}^{-}$, which may result from sea salt precipitation or domestic sewage discharge. Furthermore, the correlation coefficient $\mathrm{R}$ between $\mathrm{Na}^{+}$and $\mathrm{Cl}^{-}$is 0.472 , and that of $\mathrm{K}^{+}$and $\mathrm{Cl}^{-}$is 0.813 at a 0.01 test level, which indicates that the sources of $\mathrm{K}^{+}$and $\mathrm{Cl}^{-}$are more consistent and largely due to the sea salt precipitation. However, the fluctuation ranges of $\mathrm{Na}^{+} / \mathrm{Cl}^{-}$molar ratios are relatively great, from 0.55 to 16.86 , and the mean value of 2.42 is greater than that of standard seawater (0.86) [48]. The excessive $\mathrm{Na}^{+}$indicates that there are other sources with regard to $\mathrm{Na}^{+}$, such as the chemical weathering of silicate minerals (e.g., sodium feldspar) and common salt in domestic wastewater.

Table 3. Correlations of the main ion concentrations in the LR in January 2018.

\begin{tabular}{|c|c|c|c|c|c|c|c|c|c|c|}
\hline & $\mathrm{Ca}^{2+}$ & $\mathrm{Mg}^{2+}$ & $\mathrm{Na}^{+}$ & $\mathbf{K}^{+}$ & $\mathrm{HCO}^{3-}$ & $\mathrm{Cl}^{-}$ & $\mathrm{SO}_{4}{ }^{2-}$ & $\mathrm{NO}^{3-}$ & DSi & TDS \\
\hline $\mathrm{Ca}^{2+}$ & 1 & $* *$ & & $* *$ & $* *$ & $* *$ & $* *$ & $* *$ & $* *$ & $* *$ \\
\hline $\mathrm{Mg}^{2+}$ & 0.764 & 1 & & $* *$ & $* *$ & $* *$ & $* *$ & $* *$ & $* *$ & $* *$ \\
\hline $\mathrm{Na}^{+}$ & 0.091 & 0.112 & 1 & $* *$ & & $* *$ & $*$ & $* *$ & $* *$ & \\
\hline $\mathrm{K}^{+}$ & 0.454 & 0.34 & 0.539 & 1 & $* *$ & $* *$ & $* *$ & $* *$ & $* *$ & $* *$ \\
\hline $\mathrm{HCO}^{3-}$ & 0.961 & 0.793 & 0.059 & 0.342 & 1 & $* *$ & $*$ & $* *$ & & $* *$ \\
\hline $\mathrm{Cl}^{-}$ & 0.632 & 0.483 & 0.472 & 0.813 & 0.53 & 1 & $* *$ & $* *$ & * & $* *$ \\
\hline $\mathrm{SO}_{4}{ }^{2-}$ & 0.462 & 0.497 & 0.249 & 0.46 & 0.252 & 0.509 & 1 & $* *$ & & $* *$ \\
\hline $\mathrm{NO}^{3-}$ & 0.456 & 0.386 & 0.298 & 0.823 & 0.333 & 0.744 & 0.493 & 1 & & $* *$ \\
\hline DSi & -0.352 & -0.309 & 0.33 & -0.031 & -0.338 & -0.274 & -0.145 & -0.105 & 1 & $* *$ \\
\hline TDS & 0.981 & 0.834 & 0.156 & 0.528 & 0.94 & 0.688 & 0.534 & 0.522 & -0.348 & 1 \\
\hline
\end{tabular}

\subsubsection{Carbonate Chemical Weathering}

$\mathrm{Ca}^{2+}$ and $\mathrm{HCO}_{3}{ }^{-}$are dominant in the river water ions of the LR (Figure 2). It is found that there are significant positive correlations between $\mathrm{Ca}^{2+}$ and $\mathrm{Mg}^{2+}, \mathrm{HCO}_{3}{ }^{-}$, TDS (Table 3), with correlation coefficients of $0.764,0.961$ and $0.981(p<0.01)$, which indicates that there is a consistent geological source of $\mathrm{CCW}$ for $\mathrm{Ca}^{2+}, \mathrm{Mg}^{2+}$ and $\mathrm{HCO}_{3}{ }^{-}$. Therefore, it has an important controlling effect for CCW on the geochemistry of the LR, which is consistent with the geological background of carbonate rocks, which is the main type of the basin bedrock (the distribution area of carbonate terrains accounts for more than $60 \%$ of the total basin area). $\left(\mathrm{Ca}^{2+}+\mathrm{Mg}^{2+}\right): \mathrm{HCO}_{3}{ }^{-}$molar ratios, induced by calcite and dolomite dissolution, can be expressed as Equations (1) and (2) [49]:

$$
\begin{gathered}
\text { Calcite dissolution: } \mathrm{CaCO}_{3}+\mathrm{H}_{2} \mathrm{CO}_{3} \leftrightarrows \mathrm{Ca}^{2+}+2 \mathrm{HCO}_{3}^{-} \\
\text {Dolomite dissolution: } \mathrm{Ca}_{(1-\mathrm{x})} \mathrm{Mg}_{\mathrm{x}} \mathrm{CO}_{3}+\mathrm{H}_{2} \mathrm{CO}_{3} \leftrightharpoons(1-\mathrm{x}) \mathrm{Ca}^{2+}+\mathrm{xMg}^{2+}+2 \mathrm{HCO}_{3}^{-}
\end{gathered}
$$

The relative contribution of calcite or dolomite dissolution to river solutes can be judged by the molar ratios of $\mathrm{Mg} / \mathrm{Ca}$ and $\mathrm{Mg} / \mathrm{HCO}_{3}$ due to the fact that $\mathrm{Mg}^{2+}$ is mainly derived from the dissolution of dolomite minerals in drainage basins, and carbonates are predominant and hardly affected by the dissolution of gypsum. It can be observed that the molar ratio of $\mathrm{Mg} / \mathrm{Ca}$, produced by calcite dissolution, is less than 0.1, while that of dolomite dissolution is equal to 1 (Equations (1) and (2)). The equal dissolution of calcite and dolomite yields a $\mathrm{Mg} / \mathrm{Ca}$ ratio of 0.33 and $\mathrm{Mg} / \mathrm{HCO}_{3}$ ratio of 0.125 , and the resultant $\mathrm{Mg} / \mathrm{HCO}_{3}$ ratios are 0.08 and 0.16 , which indicates that the amount of dolomite dissolution is half or twice that of calcite based on mass balance, respectively [50,51]. The calculated average values of $\mathrm{Mg} / \mathrm{Ca}$ and $\mathrm{Mg} / \mathrm{HCO}_{3}$ in the $\mathrm{LR}$ are $0.18(0.1-0.2)$ and 0.09 (0.05-0.11), respectively, indicating that the hydrochemical compositions of the LR, induced by CCW, should be attributed to the compound contributions of calcite and dolomite dissolution. Furthermore, calcite dissolution is 
the dominant source, which is also consistent with the large-scale exposure of limestone in the basin, especially in the area where the mainstream of the LR drains.

\subsubsection{Chemical Weathering of Silicates}

It has shown that the contribution of silicate weathering to $\mathrm{CO}_{2}$ consumption has often been ignored in previous studies of karst carbon sink [14,27,28,52,53], which may lead to an overestimation of the $\mathrm{CCW}$ rate and $\mathrm{CO}_{2}$ consumption associated with $\mathrm{CCW}$ in karst watersheds. The contribution of SCW to riverine DIC in karst watersheds should not be ignored. The exogenous water from the non-carbonate terrains around the karst watershed plays an important role in the karst process. For instance, the exogenous water with a relatively low $\mathrm{pH}$ and SIc will result in the severe dissolution of carbonate rocks in karst areas, which will greatly strengthen the potential of karst carbon sink [54-56]. Ford and William [57] found that the amount of carbonates dissolved in the CCW processes will be enhanced by $50 \%$ when the recharge area of exogenous water accounts for $50 \%$. On the other hand, clastic interlayers are often observed in carbonate formations and in which, the export of $\mathrm{HCO}_{3}{ }^{-}$ induced by silicate weathering cannot simply be attributed to the contribution of CCW.

Although the rate of SCW is relatively slow, it consumes atmospheric/soil $\mathrm{CO}_{2}$ on a geological time scale ( $>1 \mathrm{Ma}$ ), and which process constitutes the natural thermostat of the Earth [58]. The proportion of non-carbonate formations in the LRB is more than $30 \%$, according to the computational geometry module in ArcMap (Environmental Systems Research Institute, Inc., Redlands, CA, USA). The silicate formations are mainly distributed at the edge of the river basin, in other words, in the upstream of the mainstream and main tributaries, as well as in the lower reaches of south bank of the LR, including igneous rocks, metamorphic rocks, clastic rocks and Quaternary alluvial sediments (Figure 1), and the former dominates the non-carbonate formations.

It is generally known that SCW is one of the important natural sources of $\mathrm{K}^{+}$and $\mathrm{Na}^{+}$, for example, the chemical weathering of silicate rocks, such as granites and metamorphic rocks, can produce $\mathrm{Na}^{+}$, and that of K-feldspar and mica can produce $\mathrm{K}^{+}$. Being less polluted by human activities in the upper reaches of the LR's main tributaries, the average concentrations of $\mathrm{Na}^{+}$and $\mathrm{K}^{+}$are 113.86 and $53.12 \mu \mathrm{mol} \cdot \mathrm{L}^{-1}$, respectively, and their proportions to the total cations, respectively, account for $19.6 \%$ and $7.07 \%$. With the dilution effect of the karst water input (poor in $\mathrm{Na}^{+}$and $\mathrm{K}^{+}$), this shows a decreasing tendency in the proportions of $\mathrm{Na}^{+}$and $\mathrm{K}^{+}$to the total cations in the midstream of tributaries to the downstream, which are $14.91 \%$ and $5.32 \%$ in the middle reaches, respectively, and $13.62 \%$ and $5.06 \%$ in the lower reaches.

The DSi in the runoff mainly originates from SCW. The average concentration of DSi in the tributaries of the LR is $138.15 \mu \mathrm{mol} \cdot \mathrm{L}^{-1}$, which is slightly lower than the average value of DSi in the global rivers $\left(158 \mu \mathrm{mol} \cdot \mathrm{L}^{-1}\right)$ [41] and the upper reaches of the Sorocaba River in Southeastern Brazil, where igneous and metamorphic rocks predominate $\left(240.75 \mu \mathrm{mol} \cdot \mathrm{L}^{-1}\right)$ [59]. It is close to that of the Ganges $\left(134 \mu \mathrm{mol} \cdot \mathrm{L}^{-1}\right)$ [60], but higher than that of the Yellow River $\left(95.29 \mu \mathrm{mol} \cdot \mathrm{L}^{-1}\right)$ [61], the Sanchahe River (80-110 $\mu \mathrm{mol} \cdot \mathrm{L}^{-1}$, upstream of the Wujiang River) [62] and the Kochechum River $\left(87.5 \mu \mathrm{mol} \cdot \mathrm{L}^{-1}\right)$ in the permafrost region of Central Siberia [63]. This indicates that the ratio of silicate formation to the drainage area dominates the output of DSi in the river basin, and it also shows that the SCW process in the LRB cannot be ignored from the perspective of the DSi concentration.

It was reported above that sea salt precipitation is the main source of $\mathrm{K}^{+}$and $\mathrm{Na}^{+}$in the LR. In addition, SCW in non-carbonate formations and carbonate interlayers also contribute significantly to $\mathrm{K}^{+}$and $\mathrm{Na}^{+}$. The ratio of $\left(\mathrm{Na}^{+}+\mathrm{K}^{+}\right)$and $\left(\mathrm{Na}^{+}+\mathrm{K}^{+}+\mathrm{Cl}^{-}\right)$is used to determine the relative contributions of SCW to the riverine hydrochemical composition [64]. Calculations show that $\left(\mathrm{Na}^{+}\right.$ $\left.+\mathrm{K}^{+}\right) /\left(\mathrm{Na}^{+}+\mathrm{K}^{+}+\mathrm{Cl}^{-}\right)$varies from 0.47 to 0.95 , with an average of 0.71 . It can be assumed that the products of SCW relatively contribute $71 \%$ of $\mathrm{K}^{+}$and $\mathrm{Na}^{+}$in the $\mathrm{LR}$, without considering other sources of $\mathrm{K}^{+}$and $\mathrm{Na}^{+}$. 
There is a positive correlation between DSi and $\left(\mathrm{Na}^{+}+\mathrm{K}^{+}\right) /\left(\mathrm{Na}^{+}+\mathrm{K}^{+}+\mathrm{Cl}^{-}\right)$for the $\mathrm{LR}\left(\mathrm{R}^{2}=0.41\right.$, $p<0.01$ ) (Figure 3), which shows that the DSi content controlled by SCW increases simultaneously with the ratio of $\left(\mathrm{Na}^{+}+\mathrm{K}^{+}\right) /\left(\mathrm{Na}^{+}+\mathrm{K}^{+}+\mathrm{Cl}^{-}\right)$, indicating that the significant contribution of SCW in non-carbonate formations to $\mathrm{K}^{+}$and $\mathrm{Na}^{+}$is further confirmed in the karst basin of the LR. The lower correlation coefficient of DSi and $\left(\mathrm{Na}^{+}+\mathrm{K}^{+}\right) /\left(\mathrm{Na}^{+}+\mathrm{K}^{+}+\mathrm{Cl}^{-}\right)$may be attributed to the DSi uptake from diatoms in the case of slower velocities, as in January [65]. It consumes atmospheric/soil $\mathrm{CO}_{2}$ during the SCW process and produces $\mathrm{HCO}_{3}{ }^{-}$while releasing $\mathrm{Na}^{+}$and $\mathrm{K}^{+}$. The contents of $\mathrm{HCO}_{3}{ }^{-}$, $\mathrm{Na}^{+}$and $\mathrm{K}^{+}$should simultaneously increase. It can be seen in Table 3 that there is a significant positive correlation between $\mathrm{HCO}_{3}{ }^{-}$and $\mathrm{K}^{+}$at 0.01 levels, with a correlation coefficient of 0.342 . However, there is no correlation between $\mathrm{HCO}_{3}{ }^{-}$and $\mathrm{Na}^{+}$, and the correlation coefficient is only 0.059 , which indicates that $\mathrm{Na}^{+}$also has other sources, except for sea salt precipitation and SCW, which is probably related to the discharge of domestic sewage from the residents of cities and towns near the riverbank.

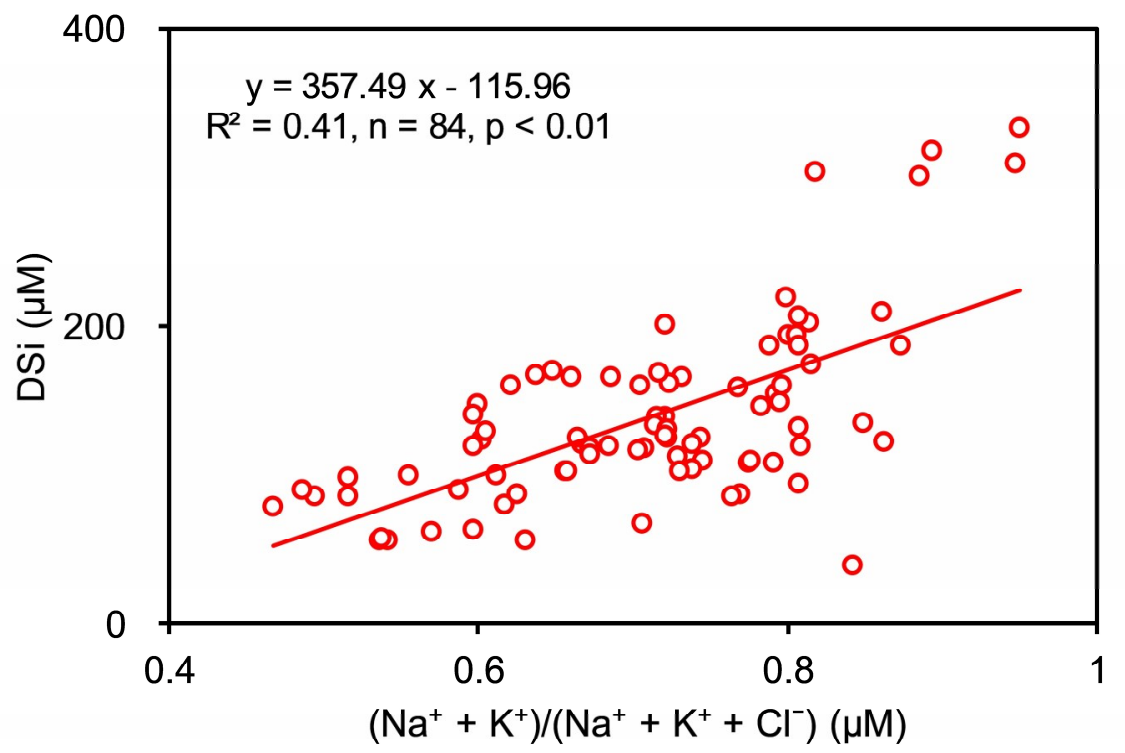

Figure 3. Relationship between DSi and $\left(\mathrm{Na}^{+}+\mathrm{K}^{+}\right) /\left(\mathrm{Na}^{+}+\mathrm{K}^{+}+\mathrm{Cl}^{-}\right)$in the LR in January 2018 .

\subsubsection{Human Activities}

Human activities, including atmospheric acid precipitation, urban and industrial wastewater, agricultural fertilization and other sources of pollution will affect river hydrochemical composition [66]. Acid precipitation and industrial wastewater mainly impact $\mathrm{SO}_{4}{ }^{2-}$ and $\mathrm{NO}_{3}{ }^{-}$in surface runoff. $\mathrm{Na}^{+}$, $\mathrm{Cl}^{-}$and $\mathrm{NO}_{3}{ }^{-}$will increase if the domestic sewage drains into the river system. The application of potassium and nitrogen fertilizer in agriculture activities results in non-point source pollution and increases the concentrations of $\mathrm{K}^{+}$and $\mathrm{NO}_{3}{ }^{-}$in the river water, respectively [66,67].

The LRB is influenced by a large amount of $\mathrm{SO}_{2}$ and $\mathrm{NO}_{x}$ from the industrial districts in north of the Nanling Mountains and the PRD, which is one of the most developed areas in East Asia. The middle and long distance transmission of acid substances has a profound impact on the northern part of Guangdong Province. The contribution rate of acid substances, transported from external lands to local acid rain, can reach $49 \%$, according to previous research on rainfall by stable isotope techniques [68]. Therefore, the urbanization/industrialization of the PRD and industrial districts in north of the Nanling Mountains is a non-negligible factor that results in a low $\mathrm{pH}$ of rainfall in the LRB. Several cities, such as Lianzhou, Liannan, and Yangshan, are distributed in the upper and middle reaches of the LR, where the population density is relatively high. In addition, it is inevitable that agricultural activities, scattered near the main tributaries, will also influence the chemical composition of the LR. 
The concentrations of $\mathrm{SO}_{4}{ }^{2-}$ and $\mathrm{NO}_{3}{ }^{-}$in the mainstream of the $\mathrm{LR}$ (Sample 3) are 165.63 and $91.94 \mu \mathrm{mol} \cdot \mathrm{L}^{-1}$, respectively, which is close to those of the Qiantangjiang River $\left(223\right.$ and $\left.146 \mu \mathrm{mol} \cdot \mathrm{L}^{-1}\right)$, which is affected by severe acid precipitation [26], but much less than those of the upper reaches in the Wujiang River (590 and $200 \mu \mathrm{mol} \cdot \mathrm{L}^{-1}$ ), which is drained in the Guizhou karst plateau and is significantly influenced by industrial activities and acid rain [53]. The ratio between $\mathrm{SO}_{4}{ }^{2-} / \mathrm{Ca}^{2+}$ and $\mathrm{NO}_{3}{ }^{-} / \mathrm{Ca}^{2+}$ is generally used to determine the anthropogenic sources of $\mathrm{SO}_{4}{ }^{2-}$ and $\mathrm{NO}_{3}{ }^{-}$. $\mathrm{NO}_{3}{ }^{-} / \mathrm{Ca}^{2+}$ is not correlated with $\mathrm{SO}_{4}{ }^{2-} / \mathrm{Ca}^{2+}$ in the mainstream and major tributaries of the LR (Figure 4), indicating that there are different sources for $\mathrm{SO}_{4}{ }^{2-}$ and $\mathrm{NO}_{3}{ }^{-}$. Several samples have a relatively high $\mathrm{SO}_{4}{ }^{2-} / \mathrm{Ca}^{2+}(>0.3)$ and low $\mathrm{NO}_{3}{ }^{-} / \mathrm{Ca}^{2+}(<0.5)$, indicating that these samples are more subject to wastewater, which is relevant to industry and mining in the upstream of some tributaries, while another small group of samples from the upstream and downstream of some tributaries have a lower $\mathrm{SO}_{4}{ }^{2-} / \mathrm{Ca}^{2+}(<0.3)$ and higher $\mathrm{NO}_{3}{ }^{-} / \mathrm{Ca}^{2+}(>1.5)$ and are connected with domestic sewage discharge, which can be demonstrated by the human activities of town residents in karst depressions and karst valleys within the LRB. As the sampling was conducted during a period with hardly any agricultural activities (January), the effect of nitrogen application on $\mathrm{NO}_{3}{ }^{-}$was neglected in this study. Most of the samples have a relatively low $\mathrm{SO}_{4}{ }^{2-} / \mathrm{Ca}^{2+}$ (average value is 0.16 ) and $\mathrm{NO}_{3}{ }^{-} / \mathrm{Ca}^{2+}$ (average value is 0.68) (Figure 4), therefore, $\mathrm{SO}_{4}{ }^{2-}$ and $\mathrm{NO}_{3}{ }^{-}$in the river water are largely due to acid precipitation, and this phenomenon is consistent with the fact that the LRB is located in a severe acid rain area in East Asia (Figure 1).

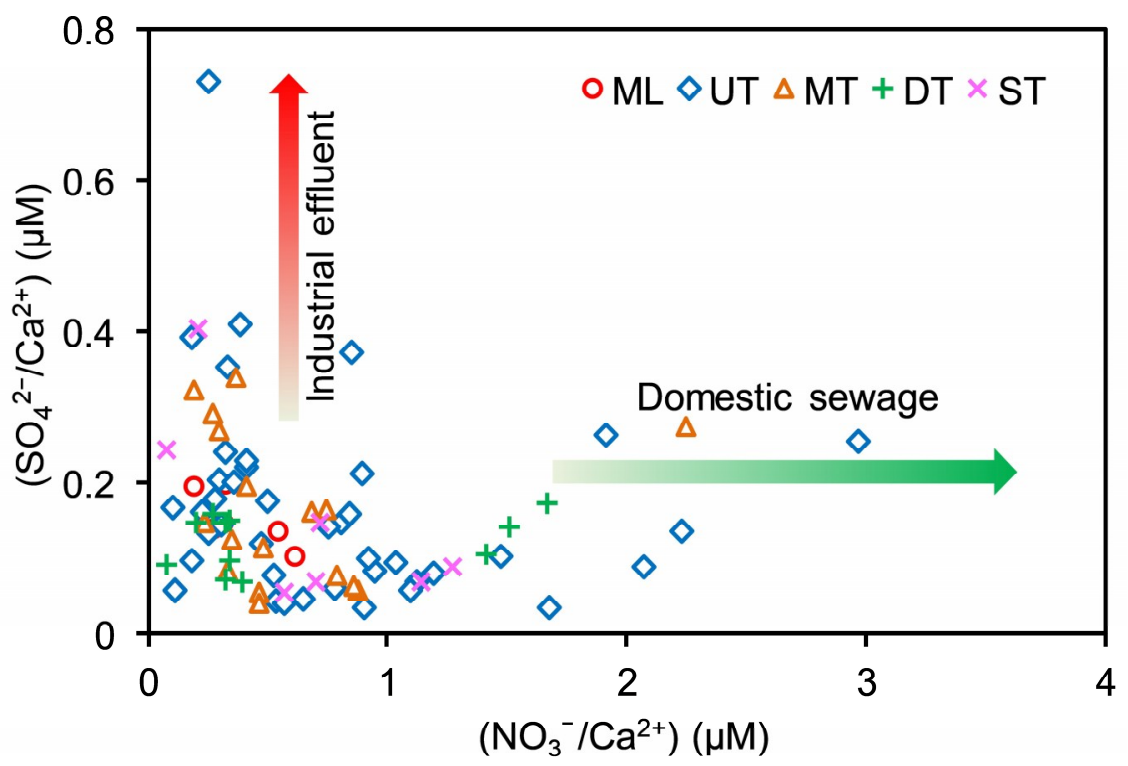

Figure 4. Relationship between concentration values of $\mathrm{SO}_{4}{ }^{2-} / \mathrm{Ca}^{2+}$ and $\mathrm{NO}_{3}{ }^{-} / \mathrm{Ca}^{2+}$ in the $\mathrm{LR}$ in January 2018.

\subsection{Evidence of Chemical Weathering Associated with Sulfuric and Nitric Acids}

Equivalent data points of $\left[\mathrm{Ca}^{2+}+\mathrm{Mg}^{2+}\right]$ and $\left[\mathrm{HCO}_{3}{ }^{-}\right]$in the $\mathrm{LR}$ deviate from the 1:1 line (Figure 5a), with most situated above the 1:1 line, indicating that extra anions are necessary to balance the excess $\mathrm{Ca}^{2+}$ and $\mathrm{Mg}^{2+}$. Nevertheless, those of $\left[\mathrm{Ca}^{2+}+\mathrm{Mg}^{2+}\right]$ and $\left[\mathrm{HCO}_{3}{ }^{-}+\mathrm{SO}_{4}{ }^{2-}+\mathrm{NO}_{3}{ }^{-}\right]$are close to the 1:1 line (Figure $5 \mathrm{~b}$ ), of which average ratio is 0.96 . Therefore, the equilibrium between the anions and cations in the $\mathrm{LR}$ requires $\mathrm{SO}_{4}{ }^{2-}$ and $\mathrm{NO}_{3}{ }^{-}$to compensate. 

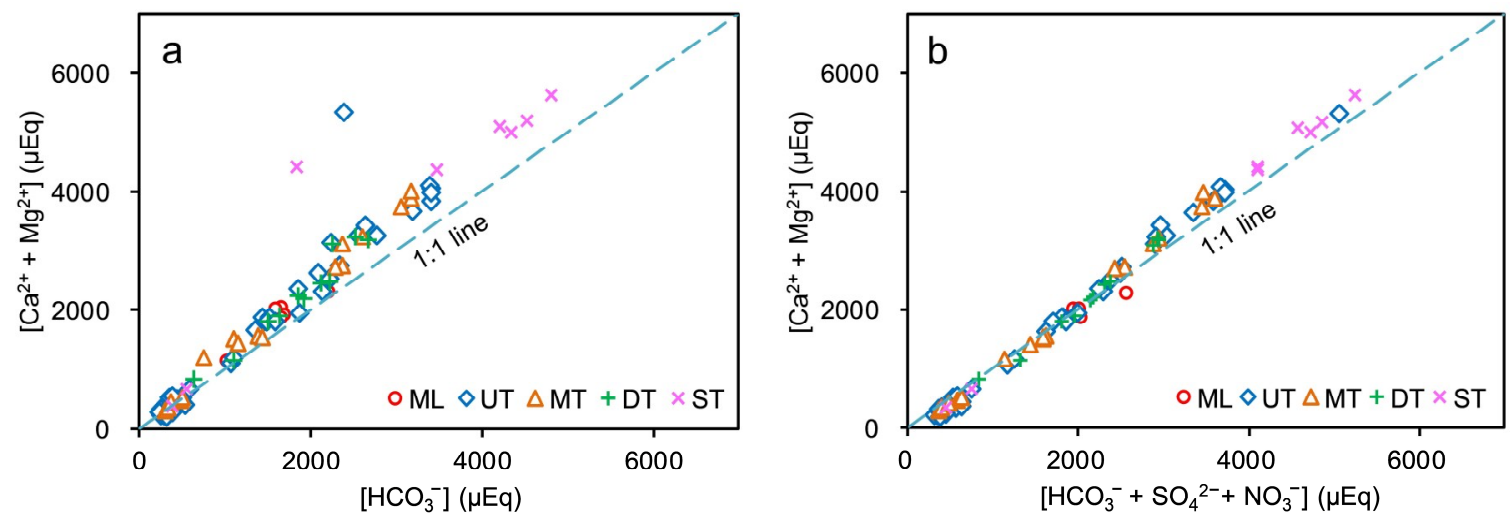

Figure 5. (a) Relationship between $\left[\mathrm{Ca}^{2+}+\mathrm{Mg}^{2+}\right]$ and $\left[\mathrm{HCO}_{3}{ }^{-}\right]$; and (b) relationship between $\left[\mathrm{Ca}^{2+}+\right.$ $\left.\mathrm{Mg}^{2+}\right]$ and $\left[\mathrm{HCO}_{3}{ }^{-}+\mathrm{SO}_{4}{ }^{2-}+\mathrm{NO}_{3}{ }^{-}\right]$.

Furthermore, the equivalent ratio between $\left[\mathrm{Ca}^{2+}+\mathrm{Mg}^{2+}\right]$ and $\left[\mathrm{HCO}_{3}^{-}\right]$should be 1 , and that of $\left[\mathrm{NO}_{3}{ }^{-}+\mathrm{SO}_{4}{ }^{2-}\right]$ and $\left[\mathrm{HCO}_{3}{ }^{-}\right]$should be zero under the condition that the $\mathrm{CCW}$ only involves carbonic acid but without exogenous acid, such as sulfuric acid and nitric acid [69]. Equivalent ratios of $\left[\mathrm{Ca}^{2+}+\mathrm{Mg}^{2+}\right]$ and $\left[\mathrm{HCO}_{3}{ }^{-}\right]$in the LR vary between 0.62 and 2.4, with an average of 1.17 , and most of the ratios are greater than $1 .\left[\mathrm{NO}_{3}{ }^{-}+\mathrm{SO}_{4}{ }^{2-}\right] /\left[\mathrm{HCO}_{3}{ }^{-}\right]$ratios vary from 0.05 to 1.24 , with an average of 0.23 , revealing that both anthropogenic sulfuric acid and nitric acid are involved in the chemical weathering process of the LRB as acid agents.

The chemical reaction equation of CCW induced by nitric acid and sulfuric acid can be expressed as Equation (3) $[19,53]$. It can be observed that the equivalent ratio of $\left[\mathrm{Ca}^{2+}+\mathrm{Mg}^{2+}\right] /\left[\mathrm{HCO}_{3}{ }^{-}\right]$, produced by CCW associated with sulfuric acid and nitric acid, is 2, and that of $\left[\mathrm{NO}_{3}{ }^{-}+\right.$ $\left.\mathrm{SO}_{4}{ }^{2-}\right] /\left[\mathrm{HCO}_{3}{ }^{-}\right]$is 1 .

$$
3 \mathrm{Ca}_{(1-\mathrm{x})} \mathrm{Mg}_{\mathrm{x}} \mathrm{CO}_{3}+\mathrm{H}_{2} \mathrm{SO}_{4}+\mathrm{HNO}_{3} \leftrightarrows 3(1-\mathrm{x}) \mathrm{Ca}^{2+}+3 \mathrm{xMg}^{2+}+\mathrm{SO}_{4}^{2-}+\mathrm{NO}_{3}^{-}+3 \mathrm{HCO}_{3}^{-}
$$

It shows that the data points of $\left[\mathrm{Ca}^{2+}+\mathrm{Mg}^{2+}\right] /\left[\mathrm{HCO}_{3}{ }^{-}\right]$and $\left[\mathrm{NO}_{3}{ }^{-}+\mathrm{SO}_{4}{ }^{2-}\right] /\left[\mathrm{HCO}_{3}{ }^{-}\right]$are distributed between the endmember of carbonic acid-involved CCW and nitric acid and sulfuric acid-involved weathering in Figure 6, which demonstrates that nitric acid and sulfuric acid play important roles in CCW, and once again proves that carbonic acid is not the only weathering medium in the LRB from this distribution pattern.

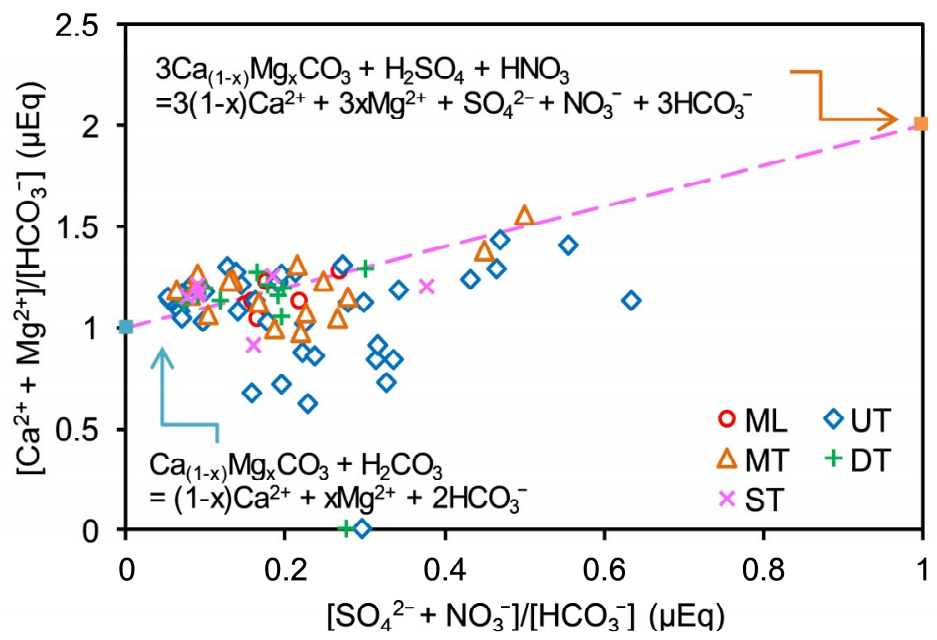

Figure 6. Relationship between equivalent ratios of $\left[\mathrm{Ca}^{2+}+\mathrm{Mg}^{2+}\right] /\left[\mathrm{HCO}_{3}{ }^{-}\right]$and $\left[\mathrm{NO}_{3}{ }^{-}+\right.$ $\left.\mathrm{SO}_{4}{ }^{2-}\right] /\left[\mathrm{HCO}_{3}{ }^{-}\right]$in the LR in January 2018. 


\subsection{Chemical Weathering and the Related $\mathrm{CO}_{2}$ Consumption Driven by Anthropogenic Acids}

\subsubsection{Influence from Sea Salt Precipitation and SCW}

The riverine DIC is composed of bicarbonate $\left(\mathrm{HCO}_{3}{ }^{-}\right)$, carbonate ions $\left(\mathrm{CO}_{3}{ }^{2-}\right)$, true carbonic acid $\left(\mathrm{H}_{2} \mathrm{CO}_{3}\right)$ and aqueous carbon dioxide $\left(\mathrm{CO}_{2 \mathrm{aq}}\right)$ [70]. $\mathrm{HCO}_{3}{ }^{-}$is the most abundant dissolved carbonate species in the LR, accounting for $94.6 \%$ of DIC. Additionally, almost all of the alkalinity in the LR is contributed by $\mathrm{HCO}_{3}{ }^{-} . \mathrm{HCO}_{3}{ }^{-}$can be regarded as DIC because the $\mathrm{pH}$ in the LR is lower than 10 [71].

Based on the above analysis, the contribution of sea salt precipitation and SCW to DIC must be subtracted from the total riverine DIC to calculate the effect of acid precipitation on DIC. Sea salt correction (see Section 4.1.1) was used to evaluate the contribution of a sea salt precipitation endmember to riverine DIC in this work. The calculated contribution proportion of sea salt precipitation to DIC concentration is very small, only accounting for $0.01 \%$, which is because the $\mathrm{pH}$ of rainwater in the LRB is below 5.6 (Figure 1), and the $p \mathrm{CO}_{2}$ in the river water is generally higher than that in the atmosphere.

The hydrochemical characteristics of the LR are mainly controlled by the geological background of the watershed. The chemical weathering of carbonate has a dominant role in riverine DIC. Additionally, SCW cannot be ignored. The reactions of SCW followed Mortatti and Probst [72], which are shown as follows:

$$
\begin{gathered}
\mathrm{Ca}_{\mathrm{x}} \mathrm{Mg}(1-\mathrm{x}) \mathrm{Al}_{2} \mathrm{Si}_{2} \mathrm{O}_{8}+2 \mathrm{H}_{2} \mathrm{CO}_{3}+2 \mathrm{H}_{2} \mathrm{O} \rightarrow \mathrm{xCa}{ }^{2+}+(1-\mathrm{x}) \mathrm{Mg}^{2+}+2 \mathrm{HCO}_{3}^{-}+2 \mathrm{SiO}_{2}+2 \mathrm{Al}(\mathrm{OH})_{3} \\
\mathrm{Na}_{x} \mathrm{~K}_{(1-\mathrm{x})} \mathrm{Al}_{2} \mathrm{Si}_{2} \mathrm{O}_{8}+\mathrm{H}_{2} \mathrm{CO}_{3}+\mathrm{H}_{2} \mathrm{O} \rightarrow \mathrm{xNa}^{+}+(1-\mathrm{x}) \mathrm{K}^{+}+\mathrm{HCO}_{3}{ }^{-}+3 \mathrm{SiO}_{2}+\mathrm{Al}(\mathrm{OH})_{3}
\end{gathered}
$$

Since SCW associated with sulfuric acid and nitric acid cannot produce $\mathrm{HCO}_{3}{ }^{-}$, the carbonic acid-involved SCW was only considered to estimate the $\mathrm{CO}_{2}$ consumption of SCW in this paper. According to Equations (4) and (5), the $\mathrm{HCO}_{3}{ }^{-}$generated from SCW can be calculated as half of the DSi concentration, and the ions of $\mathrm{Ca}^{2+}$ and $\mathrm{Mg}^{2+}$, derived from SCW, can be calculated as $1 / 5$ of the DSi concentration [73]. The calculated contribution proportions of SCW to riverine DIC range from $0.59 \%$ to $54.89 \%$, with a mean value of $9.64 \%$. The average DIC produced by SCW is $49.97 \mu \mathrm{mol} \cdot \mathrm{L}^{-1}$, indicating that the SCW plays a relatively important role in the DIC concentration of the LR.

\subsection{2. $\mathrm{CO}_{2}$ Consumption Deficit Related with Anthropogenic Acid-Involved CCW}

Carbonic acid, nitric acid and sulfuric acid were involved in CCW in the LRB. To estimate the relative contribution to riverine DIC of CCW induced by nitric and sulfuric acid, we assumed that $\mathrm{k}_{1}$ (mol) carbonic acid, $\mathrm{k}_{2}$ (mol) nitric acid and $\mathrm{k}_{3}$ (mol) sulfuric acid were involved in the CCW process, rewriting Equation (3) as [53,74]:

$$
\begin{gathered}
\left(\mathrm{k}_{1}+\mathrm{k}_{2}+2 \mathrm{k}_{3}\right) \mathrm{Ca}_{(1-\mathrm{x})} \mathrm{Mg}_{\mathrm{x}} \mathrm{CO}_{3}+\mathrm{k}_{1} \mathrm{CO}_{2}+\mathrm{k}_{1} \mathrm{H}_{2} \mathrm{O}+\mathrm{k}_{2} \mathrm{HNO}_{3}+\mathrm{k}_{3} \mathrm{H}_{2} \mathrm{SO}_{4} \rightarrow \\
\left(\mathrm{k}_{1}+\mathrm{k}_{2}+2 \mathrm{k}_{3}\right)(1-\mathrm{x}) \mathrm{Ca}^{2+}+\left(\mathrm{k}_{1}+\mathrm{k}_{2}+2 \mathrm{k}_{3}\right) \mathrm{Mgg}^{2+}+\mathrm{k}_{2} \mathrm{NO}_{3}^{-}+\mathrm{k}_{3} \mathrm{SO}_{4}^{2-}+\left(2 \mathrm{k}_{1}+\mathrm{k}_{2}+2 \mathrm{k}_{3}\right) \mathrm{HCO}_{3}^{-}
\end{gathered}
$$

Afterwards, the molar concentrations of $\left(\mathrm{Ca}^{2+}+\mathrm{Mg}^{2+}\right)$ and $\mathrm{HCO}_{3}{ }^{-}$produced by CCW in the LRB are:

$$
\begin{gathered}
{\left[\mathrm{Ca}^{2+}+\mathrm{Mg}^{2+}\right]_{\mathrm{carb}}=\mathrm{k}_{1}+\mathrm{k}_{2}+2 \mathrm{k}_{3}} \\
{\left[\mathrm{HCO}_{3}^{-}\right]_{\mathrm{carb}}=2 \mathrm{k}_{1}+\mathrm{k}_{2}+2 \mathrm{k}_{3}} \\
{\left[\mathrm{Ca}^{2+}+\mathrm{Mg}^{2+}\right]_{\mathrm{carb}}=\left[\mathrm{Ca}^{2+}+\mathrm{Mg}^{2+}\right]_{\mathrm{riv}}-\left[\mathrm{Ca}^{2+}+\mathrm{Mg}^{2+}\right]_{\mathrm{sil}}-\left[\mathrm{Ca}^{2+}+\mathrm{Mg}^{2+}\right]_{\mathrm{cyc}}} \\
{\left[\mathrm{HCO}_{3}^{-}\right]_{\mathrm{carb}}=\left[\mathrm{HCO}_{3}^{-}\right]_{\mathrm{riv}}-\left[\mathrm{HCO}_{3}{ }^{-}\right]_{\mathrm{sil}}-\left[\mathrm{HCO}_{3}^{-}\right]_{\mathrm{cyc}}}
\end{gathered}
$$

Thus:

$$
\mathrm{k}_{1}=\left[\mathrm{HCO}_{3}^{-}\right]_{\mathrm{carb}}-\left[\mathrm{Ca}^{2+}+\mathrm{Mg}^{2+}\right]_{\mathrm{carb}}
$$


In the above equations, the subscripts of "riv", "carb", "sil" and "cyc" represent the river water, carbonate weathering, silicate weathering and cyclic salt, respectively.

According to the above equations, the concentration of carbonic acid $\left(\mathrm{k}_{1}\right)$ involved in CCW can be calculated by subtracting the corresponding values of cyclic salt (sea salt precipitation) and SCW from the measured $\mathrm{HCO}_{3}{ }^{-}, \mathrm{Ca}^{2+}$, and $\mathrm{Mg}^{2+}$ concentration data at each sampling point (Equations (7)-(11)). The difference between the residual amount of $\mathrm{HCO}_{3}{ }^{-}$after deducting those from the sea salt precipitation and SCW in river water and $2 \mathrm{k}_{1}$ (the molar concentration of $\mathrm{HCO}_{3}{ }^{-}$derived from CCW by carbonic acid is double that of carbonic acid) is the sum of $k_{2}$ and $2 k_{3}$ (the values of $k_{2}$ and $k_{3}$ cannot be calculated separately). Therefore, the $k_{1}$ value can be used to calculate the molar concentrations of carbonic acid that participates in the CCW and the DIC concentrations from each endmember, respectively, and then the deficit proportion of $\mathrm{CO}_{2}$ consumption induced by nitric acid and sulfuric acid can also be calculated according to the above results.

As mentioned in Section 3.2, $\mathrm{SO}_{4}{ }^{2-}$ is abnormally high for Samples 28 and 82. To prevent the calculated results from significantly deviating from the actual ones, these two samples were not considered here. The calculation results show that the relative proportions of carbonic acid and anthropogenic acids (nitric acid and sulfuric acid) in CCW are $76.97 \%$ and $23.03 \%$, respectively. DIC from carbonic acid weathering accounts for $76.79 \%$ of the total DIC in rivers and streams, of which $38.4 \%$ is derived from atmospheric/soil $\mathrm{CO}_{2}$, and the deficit proportion of $\mathrm{CO}_{2}$ consumption, associated with CCW resulting from anthropogenic acids, is approximately $13.56 \%$. Thus, the proportion attributed to acid substances from other areas outside the LRB is $6.64 \%$ (see Section 4.1.4), and the above results show that the exogenous acid sourced from human activities has a non-negligible interference with the water-rock interaction and the geochemical cycle of carbon across the basin. The calculation of the deficit proportion is slightly lower than the loss of $\mathrm{CO}_{2}$ consumption caused by nitric acid and sulfuric acid, in both the rainy and pre-rainy seasons in the Guizhou Plateau (15.67\% and $14.17 \%$, respectively) [53], which is mainly attributed to the severe acid rain pollution, frequent industrial activity, and high percentage of carbonate rock distribution. The output of DIC, caused by anthropogenic acids in the LR, represents $38.44 \%$ of the $\mathrm{CO}_{2}$ consumption associated with natural carbonate weathering, and the proportion will reach $18.84 \%$ for the external acids, both of which are higher than that of SCW associated with nitric acid in France (6-15\%) [13]. Thus, chemical weathering influenced by human activities in the carbonate basin, especially in which affected by the heavy acid rain, need to be paid more attention.

\subsection{Response of Riverine Carbonate System to Human Activities}

It consumes $\mathrm{CO}_{2}$ from the atmosphere/soil in the chemical weathering process and directly releases the carbon sequestered in carbonate rocks during $\mathrm{CCW}$ and then, the yielded $\mathrm{HCO}_{3}{ }^{-}$are transported to the river system through surface runoff. Therefore, the chemical weathering of rocks will directly influence the riverine carbonate system [75]. A correlation analysis between $\mathrm{DIC}_{\text {riv }}$ and the parameters related with the riverine carbonate system in the LR shows that riverine TDS, $p \mathrm{CO}_{2}$, alkalinity and SIc all increase with the $\mathrm{DIC}_{\text {riv }}$ concentration, and there are extremely significant positive correlations among those parameters, with correlation coefficients of $0.975,0.633,0.999$ and 0.8 , respectively, $p<0.01$ (Table 4). Carbon dioxide, as an important driving force of the occurrence of the karst process, will promote the dissolution of carbonate rocks after entering the karst dynamic system, which represents an increase of $\mathrm{Ca}^{2+}, \mathrm{Mg}^{2+}$ and $\mathrm{HCO}_{3}{ }^{-}$, and an enhancement of $p \mathrm{CO}_{2}$. On the contrary, the escape of $\mathrm{CO}_{2}$ from the karst system may result in the carbonate precipitation, and the $\mathrm{HCO}_{3}{ }^{-}$concentration and $p \mathrm{CO}_{2}$ in river water will reduce [76]. Moreover, a constantly increasing $\mathrm{HCO}_{3}{ }^{-}$promotes the combination of $\mathrm{Ca}^{2+}$ and $\mathrm{Mg}^{2+}$ with $\mathrm{HCO}_{3}{ }^{-}$in the river water, which will lead the saturated state of calcite to be over-saturated and provide favorable conditions for calcite precipitation, thus causing a rise in $p \mathrm{CO}_{2}$. 
Table 4. Correlation analysis of parameters related with carbonate system in the LR.

\begin{tabular}{cccccccccc}
\hline & $\mathbf{T}$ & TDS & $\mathbf{p H}$ & $p \mathrm{CO}_{2}$ & Alk. & SIc & DIC $_{\mathbf{N}-\mathbf{S}}$ & DIC $_{\mathbf{C}}$ & DIC $_{\text {riv }}$ \\
\hline $\mathrm{T}$ & 1 & & & $* *$ & & & & $*$ & \\
$\mathrm{TDS}$ & 0.213 & 1 & & $* *$ & $* *$ & $* *$ & $* *$ & $* *$ & $* *$ \\
$\mathrm{pH}$ & 0.001 & 0.239 & 1 & $* *$ & $*$ & $* *$ & & $*$ & $*$ \\
$p \mathrm{CO}_{2}$ & 0.381 & 0.624 & -0.446 & 1 & $* *$ & & $* *$ & $* *$ & $* *$ \\
$\mathrm{Alk}$. & 0.234 & 0.974 & 0.284 & 0.606 & 1 & $* *$ & $* *$ & $* *$ & $* *$ \\
$\mathrm{SIc}$ & 0.231 & 0.796 & 0.706 & 0.197 & 0.813 & 1 & $* *$ & $* *$ & $* *$ \\
$\mathrm{DIC}_{\mathrm{N}-\mathrm{S}}$ & 0.141 & 0.853 & 0.112 & 0.517 & 0.785 & 0.615 & 1 & $* *$ & $* *$ \\
$\mathrm{DIC}_{\mathrm{C}}$ & 0.249 & 0.936 & 0.306 & 0.587 & 0.985 & 0.804 & 0.668 & 1 & $* *$ \\
DIC $_{\text {riv }}$ & 0.244 & 0.975 & 0.259 & 0.633 & 0.999 & 0.8 & 0.787 & 0.984 & 1 \\
\hline
\end{tabular}

** Correlation is significant at the 0.01 level (two-tailed); ${ }^{*}$ Correlation is significant at the 0.05 level (two-tailed); $\mathrm{DIC}_{\text {riv }}, \mathrm{DIC}_{\mathrm{C}}$ and $\mathrm{DIC}_{\mathrm{N}-\mathrm{S}}$ represent the total amount of DIC in water samples, DIC derived from carbonic acid-involved CCW and DIC derived from nitric acid and sulfuric acid-involved CCW, respectively.

The correlation between the $\mathrm{DIC}_{\text {riv }}$ and $\mathrm{pH}$ in the LR water is relatively weak, with a correlation coefficient of $0.259(p<0.05)$, and there is no correlation between the water temperature and $\mathrm{DIC}_{\text {riv }}$. However, there is a weak positive correlation between the water temperature and $\mathrm{DIC}_{\mathrm{C}}$, with a correlation coefficient of $0.249(p<0.05$, Table 4$)$, showing that temperature constrains the chemical weathering of carbonate rocks and have an impact on the output of DIC. Within a certain range of temperature conditions, higher temperatures give rise to faster dissolution and yields more $\mathrm{HCO}_{3}{ }^{-}$[77]. In addition, it can also reflect that there are different sources of DIC in the LR by the weak correlation between the water temperature and $\mathrm{DIC}_{\mathrm{C}}$ and the uncorrelated relationship between water temperature and $\mathrm{DIC}_{\mathrm{N}-\mathrm{S}}$, and the CCW associated with sulfuric acid and nitric acid derived from human activities, which is discussed in this paper, is one of the important sources of riverine DIC.

The participation of nitric acid and sulfuric acid in the CCW results in a weakening of carbon sequestration capacity induced by chemical weathering. In addition, it promotes the activation of carbon sequestered in carbonate rocks $[78,79] . \mathrm{HCO}_{3}{ }^{-}$, which derived from the product of chemical weathering, contributes significantly to the riverine DIC, which constitutes a non-ignorable part of the river carbon flux that transports to the ocean. There is a significant positive correlation between the DIC produced in CCW induced by carbonic acid in the LR and the total riverine DIC, with a correlation coefficient of 0.984 , and the DIC produced by anthropogenic acid-involved CCW is also positively correlated with the total DIC in river waters $(\mathrm{R}=0.787, p<0.01)$ (Table 4 and Figure $7 \mathrm{a}, \mathrm{b})$, which shows that the riverine DIC is mainly constrained by the mechanism of the CCW process induced by carbonic acid, followed by nitric acid and sulfuric acid. The DIC derived from the latter is also important for the riverine DIC in the LR. The scattered data points of $\mathrm{DIC}_{\mathrm{N}-\mathrm{S}} / \mathrm{DIC} \mathrm{C}_{\text {riv }}$ show that carbonate systems in different regions of the LRB are driven by varying degrees of weathering processes associated with nitric acid and sulfuric acid (Figure $7 b$ ). 

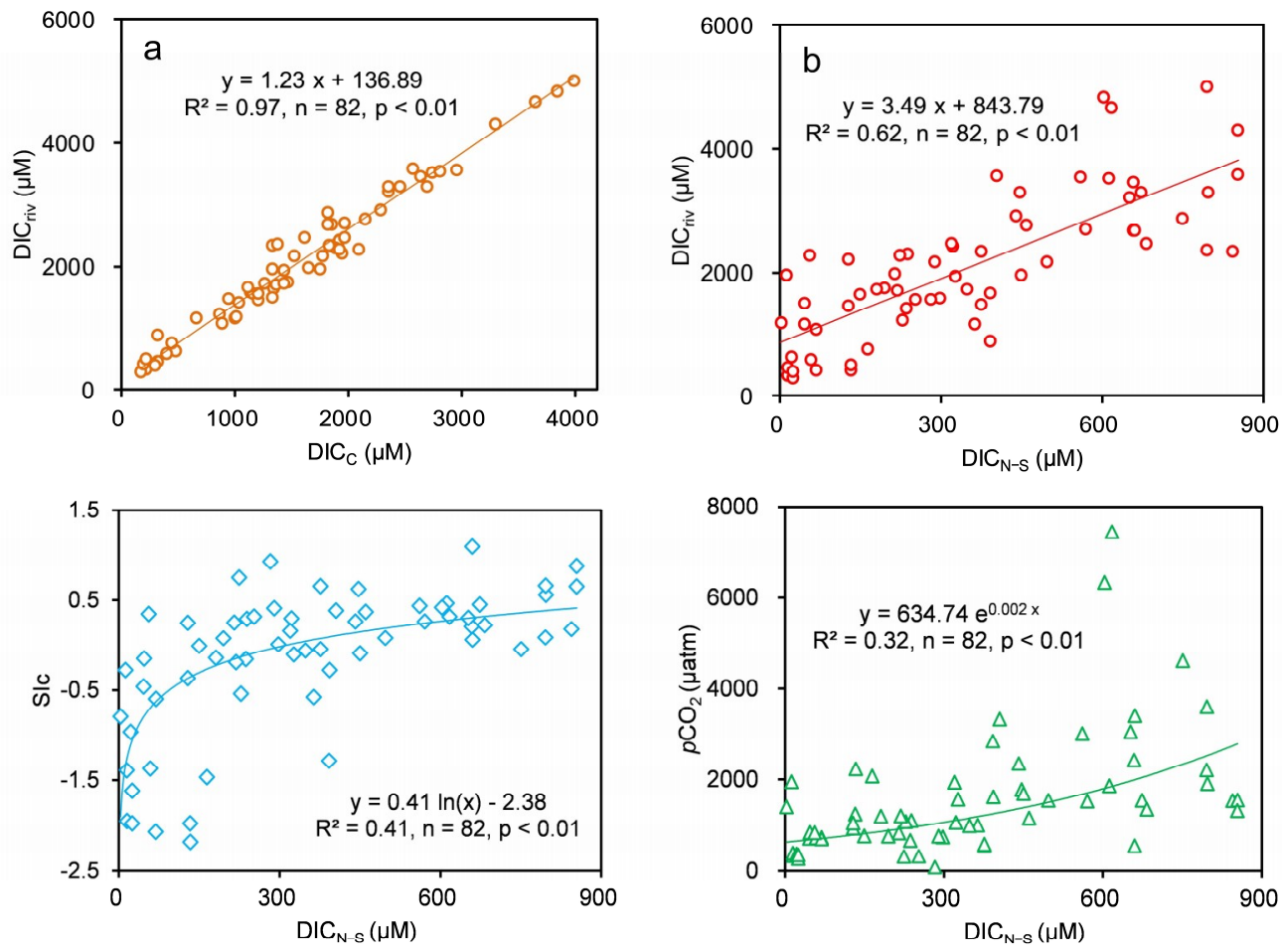

Figure 7. Relationship between DIC from different sources and the relationship among $\mathrm{DIC}-\mathrm{N}$, SIC and $p \mathrm{CO}_{2}$.

$\mathrm{DIC}_{\mathrm{N}-\mathrm{S}}$ is also significantly positively correlated with the major parameters related with the riverine carbonate system, such as TDS, $p \mathrm{CO}_{2}$, alkalinity and SIc, with the correlation coefficients of $0.853,0.517,0.785$ and $0.615(p<0.01)$ (Table 4$)$. The logarithmically increasing relationship between $\mathrm{DIC}_{\mathrm{N}-\mathrm{S}}$ and SIc $(\mathrm{R}=0.615, p<0.01)$ also indicates that the carbonate system of the LR responds positively to CCW induced by anthropogenic nitric acid and sulfuric acid (Figure 7c,d). As CCW influenced by anthropogenic acids continues to occur, carbon sequestered in carbonate rocks will continuously release into the river system, and DIC derived from CCW will also increase. The saturation state of calcite will also be gradually transformed from being unsaturated to saturated, or even oversaturated accompanied with the increase of $\mathrm{DIC}_{\mathrm{N}-\mathrm{S}}$. The increase in the saturation of calcite in river water will drive $\mathrm{CO}_{2}$ release to the atmosphere through the water-air interface, prompting the transition of the river to a carbon source [80], and, in turn, affecting the source and sink effects of drainage basins. The associated event should be considered in the estimation of the $\mathrm{CO}_{2}$ consumption induced by chemical weathering. Therefore, a systematic view of the river carbon transport process is crucial for the accurate estimation of the $\mathrm{CO}_{2}$ consumption in the drainage basin.

There is a weak exponentially increasing relationship between $\mathrm{DIC}_{\mathrm{N}-\mathrm{S}}$ and $p \mathrm{CO}_{2}(\mathrm{R}=0.517$, $p<0.01$ ), which reflects that $p \mathrm{CO}_{2}$ may be affected by other factors, except for the effects of the CCW, for instance, the terrestrial $\mathrm{CO}_{2}$ produced by root respiration will enter the river system through surface runoff, subsurface flow and groundwater [81,82]; in addition, $p \mathrm{CO}_{2}$ can also increase due to the precipitation of calcite in supersaturated water and the decomposition of organic carbon in river sediments and river waters [83,84]. In brief, chemical weathering caused by anthropogenic sulfuric acid and nitric acid is also the critical factor driving the increase of SIc and $p \mathrm{CO}_{2}$ in the LR and constrains the carbonate system of the karst river, together with the chemical weathering involved with carbonic acid. 


\section{Conclusions}

Anions and cations in the mainstream and main tributaries of the $\mathrm{LR}$ were dominated by $\mathrm{HCO}_{3}{ }^{-}$ and $\mathrm{Ca}^{2+}$ in January 2018, accounting for $84.97 \%$ of the total anions and $78.71 \%$ of the total cations, respectively. The average concentration of DSi in the drainage basin $\left(159.22 \mu \mathrm{mol} \cdot \mathrm{L}^{-1}\right)$ was slightly higher than that of global rivers $\left(158 \mu \mathrm{mol} \cdot \mathrm{L}^{-1}\right)$. Therefore, SCW in karst basins should not be ignored. $\mathrm{HCO}_{3}{ }^{-}$was the most abundant dissolved carbonate species in the LR, accounting for an average of $94.6 \%$ of DIC. Most of the dissolved loads originated from mineral weathering, dominated by calcite dissolution. $\mathrm{SO}_{4}{ }^{2-}$ and $\mathrm{NO}_{3}{ }^{-}$were mainly derived from acid precipitation, induced by acid substances from external transmission (from the PRD and industrial districts in north of the Nanling Mountains) and local supply, but the contribution from local industrial wastewater and domestic sewage was less.

The SCW contributed an average of $9.64 \%$ to riverine DIC. Sulfuric acid and nitric acid from human activities were the weathering agents that participated in the CCW. The relative proportions of carbonic acid and anthropogenic acids, participating in CCW, were $76.97 \%$ and 23.03\%, respectively. The deficit proportion of $\mathrm{CO}_{2}$ consumption, associated with $\mathrm{CCW}$ resulting from sulfuric acid and nitric acid in winter, was approximately $13.56 \%$, which was slightly lower than those of the Guizhou Plateau in the rainy and pre-rainy seasons (15.67\% and $14.17 \%$, respectively). The deficit percentage of $\mathrm{CO}_{2}$ consumption by nitric acid and sulfuric acid to the $\mathrm{CO}_{2}$ consumption associated with natural CCW was found to be $38.44 \%$ and $18.84 \%$ for anthropogenic acids from external areas, and these values may be lower than the actual values because the utilization of DIC by aquatic photosynthetic organisms was not considered in this study. In addition, the relative proportion of sulfuric acid and nitric acid, which is involved in CCW, needs to be further identified.

The DIC produced by CCW associated with nitric acid and sulfuric acid showed a significant positive correlation with riverine DIC, and there was a logarithmically increasing relationship with SIc and an exponentially increasing relationship with $p \mathrm{CO}_{2}$, indicating that the carbonate system of the LR was driven by human activities. The exogenous acids derived from human activities had a non-negligible interference with the water-rock interaction and the geochemical cycle of carbon across the basin. Therefore, the chemical weathering and riverine carbonate system, influenced by anthropogenic acids in the carbonate basin, should be paid more attention.

Author Contributions: Data curation, X.L.; Funding acquisition, Q.G.; Investigation, X.L., H.P. and M.Z.; Project administration, Z.T. and Q.G.; Visualization, X.L.; Writing-original draft, X.L.; and Writing-review and editing, Q.G.

Funding: This work was funded by the Natural Science Foundation of China (Nos. 41871014 and 41771216) and the Natural Science Foundation of Guangdong Province (Grant No. 2014A030311003).

Acknowledgments: We are particularly grateful to Zhengang Wang, Jian Ding and Peng Xu from Sun-Yat sen University for their support during the laboratory analysis and manuscript writing, and we would like to thank Wenshan Zhuo and Minsi Liang from Instrumental Analysis and Research Center, Sun Yat-sen University for their kind assistances during the sample determination. We also appreciate Zuobing Liang, Wenkui Bai and Chao Zhang for their enthusiastic and patient guidance in the process of revision.

Conflicts of Interest: The authors declare no conflict of interest.

\section{References}

1. Hedges, J.I.; Clark, W.A.; Quay, P.D.; Richey, J.E.; Devol, A.H.; Santos, U.D.M. Compositions and fluxes of particulate organic material in the Amazon River. Limnol. Oceanogr. 1986, 31, 717-738. [CrossRef]

2. Richey, J.E.; Hedges, J.I.; Devol, A.H.; Quay, P.D.; Victoria, R.; Martinelli, L.; Forsberg, B.R. Biogeochemistry of carbon in the Amazon River. Limnol. Oceanogr. 1990, 35, 352-371. [CrossRef]

3. Gaillardet, J.; Dupré, B.; Louvat, P.; Allègre, C.J. Global silicate chemical weathering and $\mathrm{CO}_{2}$ consumption rates deduced from the chemistry of large rivers. Chem. Geol. 1999, 159, 3-30. [CrossRef]

4. Cole, J.J.; Prairie, Y.T.; Caraco, N.F.; McDowell, W.H.; Tranvik, L.J.; Striegl, R.G.; Duarte, C.M.; Kortelainen, P.; Downing, J.A.; Middelburg, J.J.; et al. Plumbing the global carbon cycle: Integrating inland waters into the terrestrial carbon budget. Ecosystems 2007, 10, 171-184. [CrossRef] 
5. Tao, F.X.; Liu, C.Q.; Li, S.L. Source and flux of POC in two subtropical karstic tributaries with contrasting land use practice in the Yangtze River Basin. Appl. Geochem. 2009, 24, 2102-2112. [CrossRef]

6. Liu, Z.H.; Dreybrodt, W.; Liu, H. Atmospheric $\mathrm{CO}_{2}$ sink: Silicate chemical weathering or carbonate chemical weathering? Appl. Geochem. 2011, 26, 292-294. [CrossRef]

7. Liu, Z.H.; Dreybrodt, W.; Wang, H.J. A new direction in effective accounting for the atmospheric $\mathrm{CO}_{2}$ budget: Considering the combined action of carbonate dissolution, the global water cycle and photosynthetic uptake of DIC by aquatic organisms. Earth-Sci. Rev. 2010, 99, 162-172. [CrossRef]

8. Yang, R.; Chen, B.; Liu, H.; Liu, Z.; Yan, H. Carbon sequestration and decreased $\mathrm{CO}_{2}$, emission caused by terrestrial aquatic photosynthesis: Insights from diel hydrochemical variations in an epikarst spring and two spring-fed ponds in different seasons. Appl. Geochem. 2015, 63, 248-260. [CrossRef]

9. Chen, B.; Yang, R.; Liu, Z.H.; Sun, H.L.; Yan, H.; Zeng, Q.R.; Zeng, S.B.; Zeng, C.; Zhao, M. Coupled control of land uses and aquatic biological processes on the diurnal hydrochemical variations in the five ponds at the Shawan Karst Test Site, China: Implications for the carbonate chemical weathering-related carbon sink. Chem. Geol. 2017, 456, 58-71. [CrossRef]

10. Liu, M.X.; Xu, X.L.; Wang, D.B.; Sun, A.Y.; Wang, K.L. Karst catchments exhibited higher degradation stress from climate change than the non-karst catchments in southwest China: An ecohydrological perspective. J. Hydrol. 2016, 535, 173-180. [CrossRef]

11. Suchet, P.A.; Probst, A.; Probst, J.L. Influence of acid rain on $\mathrm{CO}_{2}$ consumption by rock weathering: Local and global scales. Water Air Soil Poll. 1995, 85, 1563-1568. [CrossRef]

12. Han, G.L.; Liu, C.Q. Water geochemistry controlled by carbonate dissolution: A study of the river waters draining karst-dominated terrain, Guizhou Province, China. Chem. Geol. 2004, 204, 1-21. [CrossRef]

13. Perrin, A.S.; Probst, A.; Probst, J.L. Impact of nitrogenous fertilizers on carbonate dissolution in small agricultural catchments: Implications for weathering $\mathrm{CO}_{2}$ uptake at regional and global scales. Geochim. Cosmochim. Acta 2008, 72, 3105-3123. [CrossRef]

14. Li, S.L.; Calmels, D.; Han, G.L.; Gaillardet, J.; Liu, C.Q. Sulfuric acid as an agent of carbonate chemical weathering constrained by $\delta^{13} \mathrm{C}_{\text {DIC }}$ : Examples from Southwest China. Earth Planet. Sci. Lett. 2008, 270, 189-199. [CrossRef]

15. Ali, H.N.; Atekwana, E.A. The effect of sulfuric acid neutralization on carbonate and stable carbon isotope evolution of shallow groundwater. Chem. Geol. 2011, 284, 217-228. [CrossRef]

16. Jiang, Y.J. The contribution of human activities to dissolved inorganic carbon fluxes in a karst underground river system: Evidence from major elements and $\delta^{13} \mathrm{C}_{\mathrm{DIC}}$ in Nandong, Southwest China. J. Contam. Hydrol. 2013, 152, 1-11. [CrossRef] [PubMed]

17. Cao, Y.J.; Tang, C.Y.; Cao, G.M.; Wang, X.Z. Hydrochemical zoning: Natural and anthropogenic origins of the major elements in the surface water of Taizi River Basin, Northeast China. Environ. Earth Sci. 2016, 75, 811. [CrossRef]

18. Ding, H.; Liu, C.Q.; Zhao, Z.Q.; Li, S.L.; Lang, Y.C.; Li, X.D.; Hu, J.; Liu, B.J. Geochemistry of the dissolved loads of the Liao River Basin in Northeast China under anthropogenic pressure: Chemical weathering and controlling factors. J. Asian Earth Sci. 2016, 138, 657-671. [CrossRef]

19. Li, X.D.; Liu, C.Q.; Liu, X.L.; Bao, L.R. Identification of dissolved sulfate sources and the role of sulfuric acid in carbonate chemical weathering using dual-isotopic data from the Jialing River, Southwest China. J. Asian Earth Sci. 2011, 42, 370-380. [CrossRef]

20. Etchanchu, D.; Probst, J.L. Evolution of the chemical composition of the Garonne River water during the period 1971-1984. Int. Assoc. Sci. Hydrol. Bull. 1988, 33, 243-256. [CrossRef]

21. Semhi, K.; Suchet, P.A.; Clauer, N.; Probst, J.L. Impact of nitrogen fertilizers on the natural weathering-erosion processes and fluvial transport in the Garonne Basin. Appl. Geochem. 2000, 15, 865-878. [CrossRef]

22. Anderson, S.P.; Drever, J.I.; Frost, C.D.; Holden, P. Chemical weathering in the foreland of a retreating glacier. Geochim. Cosmochim. Acta 2000, 64, 1173-1189. [CrossRef]

23. Martin, J.B. Carbonate minerals in the global carbon cycle. Chem. Geol. 2016, 449, 58-72. [CrossRef]

24. Li, S.L.; Chetelat, B.; Yue, F.J.; Zhao, Z.Q.; Liu, C.Q. Chemical weathering processes in the Yalong River draining the eastern Tibetan Plateau, China. J. Asian Earth Sci. 2014, 88, 74-84. [CrossRef]

25. Torres, M.A.; West, A.J.; Li, G.J. Sulphide oxidation and carbonate dissolution as a source of $\mathrm{CO}_{2}$ over geological timescales. Nature 2014, 507, 346-349. [CrossRef] [PubMed] 
26. Liu, W.J.; Shi, C.; Xu, Z.F.; Zhao, T.; Jiang, H.; Liang, C.S.; Zhang, X.; Zhou, L.; Yu, C. Water geochemistry of the Qiantangjiang River, East China: Chemical weathering and $\mathrm{CO}_{2}$ consumption in a basin affected by severe acid deposition. J. Asian Earth Sci. 2016, 127, 246-256. [CrossRef]

27. Jiang, Z.C.; Lian, Y.Q.; Qin, X.Q. Carbon cycle in the epikarst systems and its ecological effects in South China. Environ. Earth Sci. 2013, 68, 151-158. [CrossRef]

28. Zhao, M.; Liu, Z.H.; Li, H.C.; Zeng, C.; Yang, R.; Chen, B.; Yan, H. Response of dissolved inorganic carbon (DIC) and $\delta^{13} \mathrm{C}_{\mathrm{DIC}}$, to changes in climate and land cover in SW China karst catchments. Geochim. Cosmochim. Acta 2015, 165, 123-136. [CrossRef]

29. Kump, L.R.; Brantley, S.L.; Arthur, M.A. Chemical weathering, atmospheric $\mathrm{CO}_{2}$ and climate. Annu. Rev. Earth Planet. Sci. 2000, 28, 611-667. [CrossRef]

30. Hartmann, J.; Jansen, N.; Dürr, H.H.; Kempe, S.; Köhler, P. Global $\mathrm{CO}_{2}$ consumption by chemical weathering: What is the contribution of highly active weathering regions? Glob. Planet. Chang. 2009, 69, 185-194. [CrossRef]

31. Moon, S.; Chamberlain, C.P.; Hilley, G.E. New estimates of silicate weathering rates and their uncertainties in global rivers. Geochim. Cosmochim. Acta 2014, 134, 257-274. [CrossRef]

32. Zhang, G.W.; Guo, A.L.; Wang, Y.J.; Li, S.Z.; Dong, Y.P.; Liu, S.F.; He, D.F.; Cheng, S.Y.; Lu, R.K.; Yao, A.P. Tectonics of South China continent and its implications. Sci. China Ser. D 2013, 56, 1804-1828. (In Chinese) [CrossRef]

33. Lin, Q.; Xing, Y.Q. Study on Paleomagnetism in the $\varepsilon$-type Tectonic System in Northern Guangdong. Acta Geolo. Sin. 1983, 1, 63-71. (In Chinese)

34. Wang, W.X.; Xu, P.J. Research progress in precipitation chemistry in China. Prog. Chem. 2009, $21,266-281$. (In Chinese)

35. Wang, W.X.; Liang, J.Y.; Chen, Y.Z. Regional sources of acid deposition in South China. Acta. Sci. Circum. 1992, 12, 1-6. (In Chinese)

36. Tao, Z.Y.; Zheng, Y.G.; Zhang, X.L. Southern China quasi-stationary front during ice-snow disaster of January 2008. Acta Meteor. Sin. 2008, 66, 850-854. (In Chinese) [CrossRef]

37. Qin, P.; Du, Y.D.; Liu, J.L.; Song, L.L.; Liu, A.J.; Wang, Q.Q. Distributional characteristics of acid rain and its affecting factors in Guangdong Province. J. Trop. Meteor. 2006, 22, 297-300. (In Chinese) [CrossRef]

38. Gran, G. Determination of the equivalence point in potentiometric titrations, Part II, Section3: Electrical Methods. Analyst 1952, 77, 661-671. [CrossRef]

39. Geospatial Data Cloud. Available online: http://www.gscloud.cn/search (accessed on 11 December 2017).

40. Meybeck, M. Global analysis of river systems: From earth system controls to Anthropocene syndromes. Philos. T. Roy. Soc. B 2003, 358, 1935-1955. [CrossRef] [PubMed]

41. Dürr, H.H.; Meybeck, M.; Hartmann, J.; Laruelle, G.G. Global spatial distribution of natural riverine silica inputs to the coastal zone. Biogeosciences 2011, 8, 597-620. [CrossRef]

42. Zhang, Q.Z.; Tao, Z.; Ma, Z.W.; Tang, W.K.; Gao, Q.Z.; Xu, P.; Ding, J.; Liu, Z.F.; Lin, Y.W.; Su, D.; et al. Influences of anthropogenic activities on dissolved silica migration in a granite-hosted basin, Hainan Island, China. Quat. Int. 2017, 440, 99-110. [CrossRef]

43. NOAA. Available online: https://www.esrl.noaa.gov/gmd/ccgg/trends/gl_trend.html (accessed on 21 June 2018).

44. Aufdenkampe, A.K.; Mayorga, E.; Raymond, P.A.; Melack, J.M.; Doney, S.C.; Alin, S.R.; Aalto, R.E.; Yoo, K. Riverine coupling of biogeochemical cycles between land, oceans, and atmosphere. Front. Ecol. Environ. 2011, 9, 53-60. [CrossRef]

45. Viers, J.; Dupre, B.; Braun, J.J.; Freydier, R.; Greenberg, S.; Ngoupayou, J.N.; Nkamdjou, L.S. Evidence for non-conservative behaviour of chlorine in humid tropical environments. Aquat. Geochem. 2001, 7, 127-154. [CrossRef]

46. Suchet, P.A.; Probst, J.L. Modelling of atmospheric $\mathrm{CO}_{2}$ consumption by chemical weathering of rocks: Application to the Garonne, Congo and Amazon basins. Chem. Geol. 1993, 107, 205-210. [CrossRef]

47. Roy, S.; Gaillardet, J.; Allegre, C.J. Geochemistry of dissolved and suspended loads of the Seine River, France: Anthropogenic impact, carbonate and silicate weathering. Geochim. Cosmochim. Acta 1999, 63, 1277-1292. [CrossRef]

48. Grosbois, C.; Négrel, P.; Grimaud, D.; Fouillac, C. An overview of dissolved and suspended matter fluxes in the Loire River Basin: Natural and anthropogenic inputs. Aquat. Geochem. 2001, 7, 81-105. [CrossRef] 
49. Yuan, D.X.; Zhang, C. Karst dynamics theory in China and its practice. Acta Geo. Sin. 2008, 29, $355-365$. (In Chinese) [CrossRef]

50. Williams, E.L.; Szramek, K.J.; Jin, L.X.; Ku, T.C.W.; Walter, L.M. The carbonate system geochemistry of shallow groundwater-surface water systems in temperate glaciated watersheds (Michigan, USA): Significance of open-system dolomite weathering. Geol. Soc. Am. Bull. 2007, 119, 515-528. [CrossRef]

51. Zavadlav, S.; Kanduč, T.; Mclntosh, J.; Lojen, S. Isotopic and chemical constraints on the biogeochemistry of dissolved inorganic carbon and chemical weathering in the karst watershed of Krka River (Slovenia). Aquat. Geochem. 2013, 19, 209-230. [CrossRef]

52. Lang, Y.C.; Liu, C.Q.; Li, S.L.; Zhao, Z.Q.; Zhou, Z.H. Tracing natural and anthropogenic sources of dissolved sulfate in a karst region by using major ion chemistry and stable sulfur isotopes. Appl. Geochem. 2011, 26 S202-S205. [CrossRef]

53. Huang, Q.B.; Qin, X.Q.; Liu, P.Y.; Zhang, L.K.; Su, C.T. Impact of sulfuric and nitric acids on carbonate dissolution, and the associated deficit of $\mathrm{CO}_{2}$ uptake in the upper-middle reaches of the Wujiang River, China. J. Contam. Hydrol. 2017, 203, 18-27. [CrossRef] [PubMed]

54. Bögli, A. Karst Hydrology and Physical Speleology; Springer: Berlin/Heidelberg, Germany, 1980; pp. 73-76, ISBN 978-3-642-67671-0.

55. Song, L.H.; Fang, J.F.; Deng, Z.M.; Liu, H. Fractal and geometry of karst depressions in south China. Geog. Res. 1995, 14, 8-16. (In Chinese) [CrossRef]

56. Liu, Z.H.; Wu, K.Y.; Wang, J.L.; Li, Q.; Sun, H.L.; Han, J. In situ precise measurement of erosion rates of carbonate rock blocks under flowing non-karst water using micro-erosion meter and the rate-determining factors. Chin. J. Geochim. 2006, 35, 103-110. (In Chinese)

57. Ford, D.C.; William, P.W. Karst Hydrogeology and Geomorphology; John Wiley \& Sons Ltd.: Chichester, UK, 2007; pp. 1-562, ISBN 978-0-470-84996-5.

58. Strandmann, P.A.E.P.V.; Desrochers, A.; Murphy, M.J.; Finlay, A.J.; Selby, D.; Lenton, T.M. Global climate stabilisation by chemical weathering during the Hirnantian glaciation. Geochem. Perspect. Lett. 2017, 3, 230-237. [CrossRef]

59. Fernandes, A.M.; Conceição, F.T.D.; Junior, E.P.S.; Sardinha, D.D.S.; Mortatti, J. Chemical weathering rates and atmospheric/soil $\mathrm{CO}_{2}$ consumption of igneous and metamorphic rocks under tropical climate in Southeastern Brazil. Chem. Geol. 2016, 443, 54-66. [CrossRef]

60. Fontorbe, G.; Rocha, C.L.D.L.; Chapman, H.J.; Bickle, M.J. The silicon isotopic composition of the Ganges and its tributaries. Earth. Planet. Sci. Lett. 2013, 381, 21-30. [CrossRef]

61. Wang, L.; Zhang, L.J.; Cai, W.J.; Wang, B.S.; Yu, Z.G. Consumption of atmospheric $\mathrm{CO}_{2}$ via chemical weathering in the Yellow River Basin: The Qinghai-Tibet Plateau is the main contributor to the high dissolved inorganic carbon in the Yellow River. Chem. Geol. 2016, 430, 34-44. [CrossRef]

62. An, Y.L.; Hou, Yi.L.; Wu, Q.X.; Lin, Q.; Li, L.B. Chemical weathering and $\mathrm{CO}_{2}$ consumption of a high-erosion-rate karstic river: A case study of the Sanchahe River, Southwest China. Chin. J. Geochem. 2015, 34, 601-609. [CrossRef]

63. Pokrovsky, O.S.; Reynolds, B.C.; Prokushkin, A.S.; Schott, J.; Viers, J. Silicon isotope variations in central Siberian Rivers during basalt weathering in permafrost-dominated larch forests. Chem. Geol. 2013, 355, 103-116. [CrossRef]

64. Chen, J.S.; He, D.W. Chemical characteristics and genesis of major ions in the Pearl River Basin. Acta Sci. Nat. Univ. Pekinensis 1999, 35, 786-793. (In Chinese) [CrossRef]

65. Wu, W.H. Hydrochemistry of inland rivers in the north Tibetan Plateau: Constraints and weathering rate estimation. Sci. Total Environ. 2016, 541, 468-482. [CrossRef] [PubMed]

66. Chetelat, B.; Liu, C.Q.; Zhao, Z.Q.; Wang, Q.L.; Li, S.L.; Li, J.; Wang, B.L. Geochemistry of the dissolved load of the Changjiang Basin rivers: Anthropogenic impacts and chemical weathering. Geochim. Cosmochim. Acta 2008, 72, 4254-4277. [CrossRef]

67. Wu, W.H.; Zheng, H.B.; Yang, J.D.; Luo, C.; Zhou, B. Chemical weathering, atmospheric $\mathrm{CO}_{2}$ consumption, and the controlling factors in a subtropical metamorphic-hosted watershed. Chem. Geol. 2013, 356, 141-150. [CrossRef]

68. Zhang, H.B.; Hu, A.Q.; Lu, C.Z.; Zhang, G.X. Sulfur isotopic composition of acid deposition in South China Regions and its environmental significance. China Environ. Sci. 2002, 22, 165-169. (In Chinese) [CrossRef] 
69. Spence, J.; Telmer, K. The role of sulfur in chemical weathering and atmospheric $\mathrm{CO}_{2}$ fluxes: Evidence from major ions, $\delta^{13} \mathrm{C}_{\mathrm{DIC}}$, and $\delta^{34} \mathrm{~S}_{\mathrm{SO} 4}$ in rivers of the Canadian Cordillera. Geochim. Cosmochim. Acta 2005, 69, 5441-5458. [CrossRef]

70. Gao, Q.Z.; Wang, Z.G. Dissolved inorganic carbon in the Xijiang River: Concentration and stable isotopic composition. Environ. Earth Sci. 2015, 73, 253-266. [CrossRef]

71. Dreybrodt, W. Processes in Karst Systems: Physics, Chemistry, and Geology; Springer: Berlin/Heidelberg, Germany, 1988; pp. 1-283, ISBN 978-3-642-83354-0.

72. Mortatti, J.; Probst, J.L. Silicate rock weathering and atmospheric/soil $\mathrm{CO}_{2}$ uptake in the Amazon Basin estimated from river water geochemistry: Seasonal and spatial variations. Chem. Geol. 2003, 197, 177-196. [CrossRef]

73. Zhao, H.J.; Xiao, Q.; Wu, X.; Liu, F.; Miao, Y.; Jiang, Y.J. Impact of human activities on water-rock interactions in surface water of Lijiang River. J. Environ. Sci. 2017, 38, 4108-4119. (In Chinese)

74. Zhang, X.B.; Jiang, Y.J.; Qiu, S.L.; Cao, M.; Hu, Y.J. Agricultural activities and carbon cycling in Karst areas in Southwest China: Dissolving carbonate rocks and $\mathrm{CO}_{2}$ sink. Adv. Earth Sci. 2012, 27, 466-476. (In Chinese)

75. Raymond, P.A.; Cole, J.J. Increase in the export of alkalinity from North America's largest river. Science 2003, 301, 88-91. [CrossRef] [PubMed]

76. Cao, J.H.; Hu, B.; Groves, C.; Huang, F.; Yang, H.; Zhang, C.L. Karst dynamic system and the carbon cycle. Z. Geomorphol. Suppl. Issues 2016, 60, 35-55. [CrossRef]

77. Fan, M.; Jiang, X.Q.; Liu, W.X.; Zhang, J.Y.; Chen, H.Y. Dissolution of carbonate rocks in $\mathrm{CO}_{2}$ solution under the different temperatures. Acta Sedim. Sin. 2007, 25, 825-830. (In Chinese) [CrossRef]

78. Baker, A.; Cumberland, S.; Hudson, N. Dissolved and total organic and inorganic carbon in some British rivers. Area 2008, 40, 117-127. [CrossRef]

79. Barnes, R.T.; Raymond, P.A. The contribution of agriculture and urban activities to inorganic carbon fluxes within temperate watersheds. Chem. Geol. 2009, 266, 318-327. [CrossRef]

80. Zhai, W.D.; Dai, M.H.; Guo, X.H. Carbonate system and $\mathrm{CO}_{2}$ degassing fluxes in the inner estuary of Changjiang (Yangtze) River, China. Mar. Chem. 2007, 107, 342-356. [CrossRef]

81. Johnson, M.S.; Lehmann, J.; Riha, S.J.; Krusche, A.V.; Richey, J.E.; Ometto, J.P.H.B.; Couto, E.G. CO 2 efflux from Amazonian headwater streams represents a significant fate for deep soil respiration. Geophys. Res. Lett. 2008, 35, L17401. [CrossRef]

82. Abril, G.; Martinez, J.M.; Artigas, L.F.; Moreira-turcq, P.; Benedetti, M.F.; Vidal, L.; Meziane, T.; Kim, J.H.; Bernardes, M.C.; Savoye, N.; et al. Amazon River carbon dioxide outgassing fuelled by wetlands. Nature 2014, 505, 395-398. [CrossRef] [PubMed]

83. Teodoru, C.R.; Giorgio, P.A.D.; Prairie, Y.T.; Camire, M. Patterns in $p \mathrm{CO}_{2}$ in boreal streams and rivers of Northern Quebec, Canada. Glob. Biogeochem. Cycles 2009, 23, GB2012. [CrossRef]

84. Sawakuchi, H.O.; Bastviken, D.; Sawakuchi, A.O.; Ward, N.D.; Borges, C.D.; Tsai, S.M.; Richey, J.E.; Ballester, M.V.; Krusche, A.V. Oxidative mitigation of aquatic methane emissions in large Amazonian rivers. Glob. Chang. Biol. 2016, 22, 1075-1085. [CrossRef] [PubMed]

(c) 2018 by the authors. Licensee MDPI, Basel, Switzerland. This article is an open access article distributed under the terms and conditions of the Creative Commons Attribution (CC BY) license (http:/ / creativecommons.org/licenses/by/4.0/). 